\title{
Consistent simulation of bromine chemistry from the marine boundary layer to the stratosphere - Part 2: Bromocarbons
}

\author{
A. Kerkweg ${ }^{1,2}$, P. Jöckel ${ }^{1}$, N. Warwick ${ }^{3}$, S. Gebhardt ${ }^{1}$, C. A. M. Brenninkmeijer ${ }^{1}$, and J. Lelieveld ${ }^{1}$ \\ ${ }^{1}$ MPI for Chemistry (Otto Hahn Institute), Atmospheric Chemistry Department, P.O. Box 3060, 55020 Mainz, Germany \\ ${ }^{2}$ Institute for Atmospheric Physics, University of Mainz, Mainz, Germany \\ ${ }^{3}$ University of Cambridge, Chemistry Department, Lensfield Road, Cambridge, CB2 1EW, UK
}

Received: 26 February 2008 - Published in Atmos. Chem. Phys. Discuss.: 23 May 2008

Revised: 14 August 2008 - Accepted: 20 August 2008 - Published: 15 October 2008

\begin{abstract}
In this second part of a series of articles dedicated to a detailed analysis of bromine chemistry in the atmosphere we address one (out of two) dominant natural sources of reactive bromine. The two main source categories are the release of bromine from sea salt and the decomposition of bromocarbons by photolysis and reaction with $\mathrm{OH}$. Here, we focus on $\mathrm{C}_{1}$-bromocarbons. We show that the atmospheric chemistry general circulation model ECHAM5/MESSy realistically simulates their emission, transport and decomposition from the boundary layer up to the mesosphere. We included oceanic emission fluxes of the short-lived bromocarbons $\mathrm{CH}_{2} \mathrm{Br}_{2}, \mathrm{CH}_{2} \mathrm{ClBr}, \mathrm{CHClBr}_{2}, \mathrm{CHCl}_{2} \mathrm{Br}, \mathrm{CHBr}_{3}$ and of $\mathrm{CH}_{3} \mathrm{Br}$. The vertical profiles and the surface mixing ratios of the bromocarbons are in general agreement with the (few available) observations, especially in view of the limited information available and the consequent coarseness of the emission fields. For $\mathrm{CHBr}_{3}, \mathrm{CHCl}_{2} \mathrm{Br}$ and $\mathrm{CHClBr}_{2}$ photolysis is the most important degradation process in the troposphere. In contrast to this, tropospheric $\mathrm{CH}_{2} \mathrm{Br}_{2}, \mathrm{CH}_{3} \mathrm{Br}$ and $\mathrm{CH}_{2} \mathrm{ClBr}$ are more efficiently decomposed by reaction with $\mathrm{OH}$. In the free troposphere approximately $40 \%$ of the $\mathrm{C}_{1}$ bromocarbons decompose by reaction with $\mathrm{OH}$. Our results indicate that bromoform contributes substantial amounts of reactive bromine to the lower stratosphere and thus should not be neglected in stratospheric simulations.
\end{abstract}

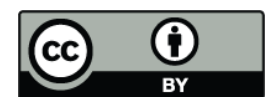

Correspondence to: A. Kerkweg (akerkweg@mpch-mainz.mpg.de)

\section{Introduction}

The abundance of bromine in the troposphere and the importance of individual bromine sources to atmospheric halogen chemistry is highly uncertain. Only few measurement data of reactive bromine precursors are available. The main sources are the release of inorganic bromine from sea salt and emissions of bromocarbons followed by photolysis or reaction with $\mathrm{OH}$. In the present study about atmospheric bromine, the focus is on $\mathrm{C}_{1}$-bromocarbons (further denoted as bromocarbons). Their emission fluxes, the transport and the main regions and processes of degradation are investigated here.

The most comprehensive model studies of bromocarbons thus far have been performed by Warwick et al. (2006a,b) who applied the Chemistry Transport Model (CTM) pTOMCAT to simulate atmospheric bromoform $\left(\mathrm{CHBr}_{3}\right)$ and other short-lived bromocarbons (Table 1 lists all abbreviations). They concluded that global source estimates using the previously used top-down approach were too low and suggested a global emission flux of about 400$600 \mathrm{Gg}\left(\mathrm{CHBr}_{3}\right) / \mathrm{yr}$. These emissions largely take place in the tropics. In addition to bromoform, Warwick et al. (2006a) investigated the short-lived bromocarbons $\mathrm{CH}_{2} \mathrm{Br}_{2}, \mathrm{CH}_{2} \mathrm{ClBr}$, $\mathrm{CHClBr}_{2}$, and $\mathrm{CHCl}_{2} \mathrm{Br}$. The emission fields of these compounds have been scaled to the emission fields of bromoform. Yang et al. (2005) were the first to use these emission fields to simulate bromine chemistry in the troposphere together with semi-prognostically calculated bromine sources from sea-salt aerosol, also using the p-TOMCAT model.

In this study we apply the emission fields proposed by Warwick et al. (2006a) in our atmospheric chemistry general circulation model (AC-GCM). As the GCM is only weakly forced towards the analysed meteorology of the European Centre for Medium-Range Weather Forecasts (ECMWF), it consistently calculates its own meteorology, whereas p-TOMCAT is driven offline by 6-hourly ECMWF data.

Published by Copernicus Publications on behalf of the European Geosciences Union. 
Table 1. List of abbreviations and acronyms.

\begin{tabular}{|c|c|}
\hline abbreviation & \\
\hline AASE-II & Airborne Arctic Stratospheric Expedition II \\
\hline AC-GCM & Atmospheric Chemistry General Circulation Model \\
\hline AIRSEA & MESSy submodel: trace gas air-sea exchange \\
\hline CARIBIC & Civil Aircraft for the Regular Investigation of the atmosphere based on an Instrument Container \\
\hline CTM & Chemistry Transport Model \\
\hline CLOUD & MESSy submodel: cloud microphysics \\
\hline CONVECT & MESSy submodel: convection parameterisation \\
\hline CVTRANS & MESSy submodel: convective transport of tracers \\
\hline DRYDEP & MESSy submodel: dry deposition of gases and aerosols \\
\hline $\mathrm{E} 5 / \mathrm{M}^{+}$ & extended ECHAM5/MESSy version 1 \\
\hline ECHAM5 & an atmospheric general circulation model \\
\hline ECMWF & European Centre of Medium-range Weather Forecasts \\
\hline $\begin{array}{l}\text { GABRIEL } \\
\text { GCM }\end{array}$ & $\begin{array}{l}\text { Guyanas Atmosphere-Biosphere exchange and Radicals Intensive Experiment with the Learjet } \\
\text { general circulation model }\end{array}$ \\
\hline $\mathrm{H} 2 \mathrm{O}$ & MESSy submodel: feedback control for chemical tendency of $\mathrm{H}_{2} \mathrm{O}$ \\
\hline HETCHEM & MESSy submodel: heterogenous chemistry \\
\hline JVAL & MESSy submodel: photolysis rates \\
\hline L87 & abbr. for vertical number of layers ( $\mathrm{L} 87=87$ vertical layers) \\
\hline LNOX & MESSy submodel: Lightning $\mathrm{NO}_{\mathrm{x}}$ \\
\hline M7 & MESSy submodel: aerosol dynamical model \\
\hline MAECHAM5 & middle atmosphere setup of ECHAM5 \\
\hline MBL & Marine Boundary Layer \\
\hline MECCA (-AERO) & MESSy submodel: gas and aerosol phase chemistry \\
\hline MESSy & Modular Earth Submodel System \\
\hline MINOS & Mediterranean Intensive Oxidant Study \\
\hline OFFLEM & MESSy submodel: calculating offline emissions \\
\hline ONLEM & MESSy submodel: calculating online emissions \\
\hline PARFORCE & Particle Formation and Fate in the Coastal Environment, measurement campaign \\
\hline PEM & Pacific Exploratory Mission \\
\hline PSC & MESSy submodel: polar stratospheric clouds \\
\hline RAD4ALL & MESSy submodel: radiation \\
\hline QBO & Quasi-Biennial Oscillation (process and MESSy submodel) \\
\hline SCAV & MESSy submodel: scavenging and cloud chemistry of gases and aerosol particles \\
\hline SEDI & MESSy submodel: sedimentation of aerosol particles \\
\hline SOAPEX & Southern Ocean Atmospheric Photochemistry EXperiment, measurement campaign \\
\hline STRAT & Stratospheric Tracers of Atmospheric Transport \\
\hline TOMCAT & a CTM \\
\hline TROPOP & MESSy submodel: diagnostics of tropopause and boundary layer height \\
\hline UTLS & upper troposphere/lower stratosphere \\
\hline
\end{tabular}

Furthermore, our model also includes the middle atmosphere (up to $\approx 80 \mathrm{~km}$ ) and realistically simulates the exchange between stratosphere and troposphere (STE) in the applied vertical resolution. This has been shown by Jöckel et al. (2006) by analysing the $\mathrm{O}_{3}$-budget and by comparison of simulated $\mathrm{O}_{3}$-profiles with observations. The p-TOMCAT model domain, in contrast, is restricted to below $30 \mathrm{~km}$ altitude. Hence, the two models differ inevitably in the dynamics consequently evoking differences in the simulated bromocarbon distributions.
Only few measurement data sets are available for an evaluation of the simulation results. Surface mixing ratios have often been observed in coastal regions, but at these locations bromocarbon emissions are usually higher than over the open ocean. Thus, many measurements have to be interpreted as upper limits, as coastlines and surf effects can not be resolved in a model with a horizontal resolution of approximately $250 \mathrm{~km}$. Information about the vertical distribution of bromocarbons is even harder to obtain, since satellite observations of these species are not available. 

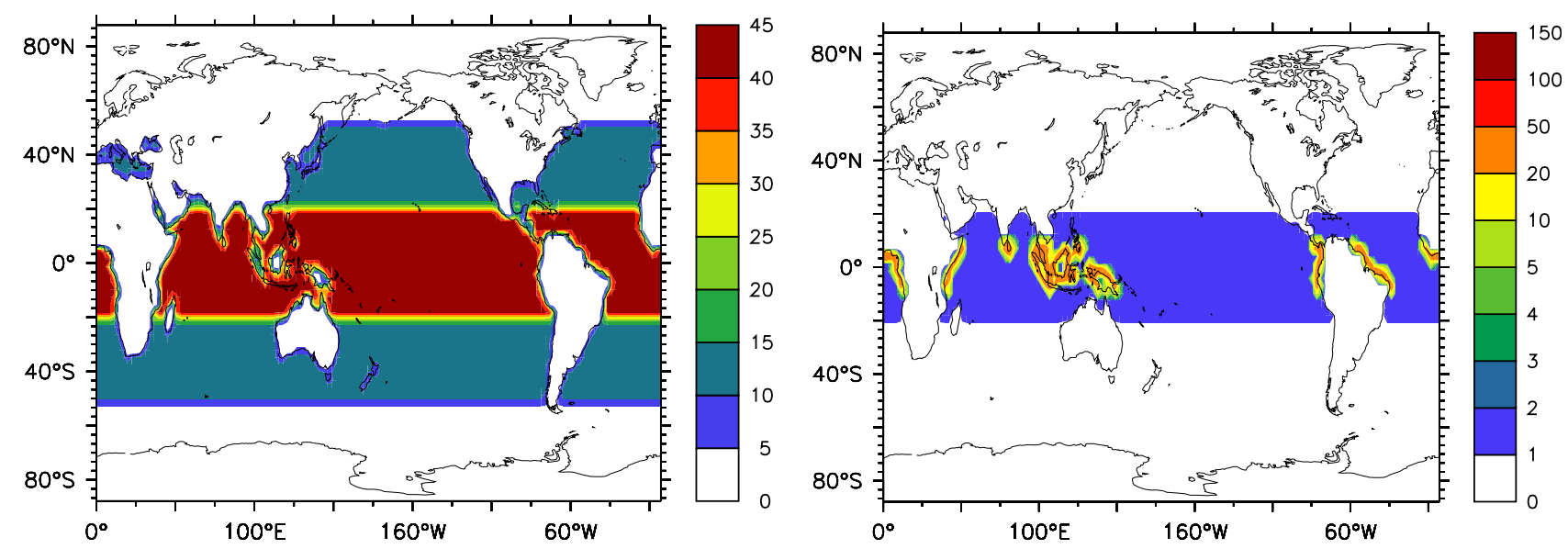

Fig. 1. Annually integrated bromocarbon emission fluxes for $\mathrm{CH}_{2} \mathrm{ClBr}$ (left, $\left.\mu \mathrm{g} /\left(\mathrm{m}^{2} \mathrm{yr}\right)\right)$ and $\mathrm{CHBr}_{3}\left(\mathrm{right}, \mathrm{mg} /\left(\mathrm{m}^{2} \mathrm{yr}\right)\right)$.

Thus the only source of vertically resolved information are aircraft measurements. The three data sets used here are from

- CARIBIC1 (1997-2001, Brenninkmeijer et al., 1999),

- the Pacific Exploratory Mission(s) (PEM): PEM-West B (February-March 1994, Hoell et al., 1997), PEMTropics A (August-October 1996, Hoell et al., 1999) and PEM-Tropics B (March-April 1999, Raper et al., 2001) and from

- the GABRIEL campaign (October 2005, Stickler et al., 2007; Lelieveld et al., 2008).

Section 2 describes the model setup. In Sect. 3 the simulated distributions of $\mathrm{CHBr}_{3}, \mathrm{CH}_{2} \mathrm{Br}_{2}, \mathrm{CH}_{2} \mathrm{ClBr}, \mathrm{CHClBr}_{2}$, $\mathrm{CHCl}_{2} \mathrm{Br}$ and $\mathrm{CH}_{3} \mathrm{Br}$ are evaluated. The relative importance of photolysis and the reaction with $\mathrm{OH}$ of the bromocarbons as a source of reactive bromine is discussed in Sect. 4. Finally, the results are summarised in Sect. 5.

\section{Model description}

For the first comprehensive study of bromine chemistry in the boundary layer (BL), the free troposphere (FT) and the stratosphere, the ECHAM5/MESSy $1^{+}\left(\mathrm{E} 5 / \mathrm{M1}^{+}\right)$model is applied. The model system consists of the general circulation model ECHAM5 (Roeckner et al., 2003, 2004, 2006) and the Modular Earth Submodel System (MESSy, Jöckel et al., 2005, 2006). For this study the middle atmosphere setup of ECHAM5, (MAECHAM5; Giorgetta et al., 2002, 2006) has been applied in the T42L87 resolution, i.e. with a triangular truncation at wave number 42 for the spectral core of ECHAM5. This corresponds to a quadratic Gaussian grid of approximately $2.8^{\circ} \times 2.8^{\circ}$ in latitude and longitude, with
87 vertical levels on a hybrid-pressure grid, reaching up to $0.01 \mathrm{hPa}$ (middle of the uppermost layer). The model time step is $720 \mathrm{~s}$. Instantaneous data output is triggered every five hours.

The following submodels included in MESSy were switched on: cloud formation (submodel CLOUD), convection (CONVECT; Tost et al., 2006b, 2007b), convective tracer transport (CVTRANS), scavenging of trace gases and aerosols and wet deposition (SCAV; Tost et al., 2006a), gas and aerosol phase chemistry (MECCA(-AERO); Sander et al., 2005; Kerkweg et al., 2007), photolysis (JVAL; Landgraf and Crutzen, 1998) and heterogeneous chemistry in the stratosphere (HETCHEM), online and offline emissions as well as tracer nudging (ONLEM, OFFLEM and TNUDGE; Kerkweg et al., 2006b), the air-sea exchange of acetone and methanol (AIRSEA; Pozzer et al., 2006), emission of $\mathrm{NO}_{\mathrm{x}}$ from lightning (LNOX; Tost et al., 2007a), aerosol dynamics (M7; Vignati et al., 2004; Kerkweg et al., 2008), dry deposition of trace gases and aerosols (DRYDEP; Kerkweg et al., 2006a) calculated following the big leaf approach of Wesely (1989), sedimentation of aerosols (SEDI; Kerkweg et al., 2006a), radiation feedback (RAD4ALL), nudging of the QBO (QBO), polar stratospheric clouds (PSC; Buchholz, 2005) and TROPOP (used to determine the tropopause and the boundary layer height).

The individual submodels of the setup are described by Jöckel et al. (2006) and Kerkweg et al. (2008). Previously, atmospheric bromine was represented by prescribing $\mathrm{CH}_{3} \mathrm{Br}$ and halon mixing ratios $\left(\mathrm{CH}_{3} \mathrm{Cl}, \mathrm{CFCl}_{3}, \mathrm{CH}_{3} \mathrm{CCl}_{3}\right.$, $\mathrm{CCl}_{4}, \mathrm{CF}_{2} \mathrm{BrCl}, \mathrm{CF}_{3} \mathrm{Br}$ ) at the surface based on observations (Jöckel et al., 2006), whereas in the present study five additional bromocarbons are taken into account. Hence, we provide details about the submodels which are of special importance for the current study. 
Table 2. List of surface measurements (average, minimum and maximum) of $\mathrm{CHBr}_{3}(\mathrm{pmol} / \mathrm{mol})$ in the mid-latitudes and tropics.

\begin{tabular}{llcrrr}
\hline Reference & Location & Time & mean & $\min$ & $\max$ \\
\hline Penkett et al. (1985) & Atlantic Ocean NH & $1982 / 1983$ & 0.85 & 0.41 & 1.29 \\
& Atlantic/Southern Ocean SH & & 0.58 & 0.28 & 0.88 \\
Class and Ballschmiter (1988) & Atlantic Ocean & 1985 & 2 & 0.5 & $>200$ \\
Atlas et al. (1992) & Hawaii & May-Jun 1988 & 0.22 & 0.08 & 0.41 \\
Yokouchi et al. (1997) & western Pacific 1 & Feb 1991 & 1.01 & 0.28 & 2.9 \\
& western Pacific 2 & Sep-Oct 1992 & 0.63 & 0.13 & 1.91 \\
& Asian coast & Feb 1994 & 1.2 & 0.32 & 7.1 \\
Ramacher et al. (1999) & Ny Ålesund & Apr-May 1996 & 0.65 & $<0.1$ & 1.9 \\
Carpenter et al. (1999) & Mace Head & May 1997 & 6.3 & 1.9 & 16.3 \\
Carpenter and Liss (2000) & Mace Head & Sep 1998 & 6.8 & 1.0 & 22.7 \\
& Cape Grim & & 2.6 & 0.6 & 8.0 \\
Carpenter et al. (2005) & Mace Head & May 2001-Dec 2003 & & & \\
& & Mar-Oct & 5.3 & 4.3 & 6.3 \\
& & Oct-Mar & 1.8 & 1.0 & 2.6 \\
\hline
\end{tabular}

${ }^{a}$ PARFORCE campaign, ${ }^{b}$ SOAPEX 2 campaign. NH Northern Hemisphere, SH Southern Hemisphere.

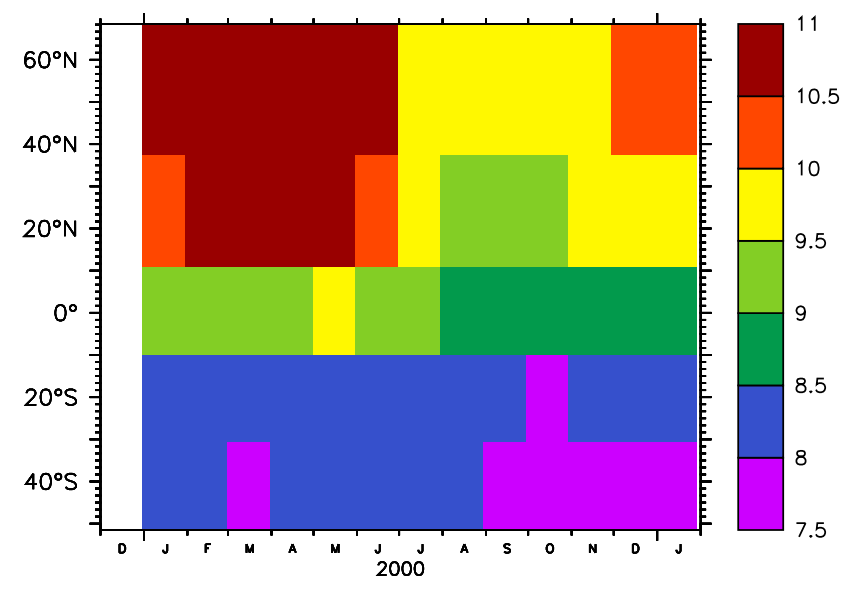

Fig. 2. Year 2000 annual cycle of the surface $\mathrm{CH}_{3} \mathrm{Br}$ mixing ratios ( $\mathrm{pmol} / \mathrm{mol}$ ) as used by the submodel TNUDGE.

Bromocarbon emissions are included using the annually averaged emission fields as provided by Warwick et al. (2006a). They are processed by the submodel OFFLEM (Kerkweg et al., 2006b). Figure 1 shows the emission fields for $\mathrm{CH}_{2} \mathrm{ClBr}$ and bromoform $\left(\mathrm{CHBr}_{3}\right)$. The emission fluxes of $\mathrm{CHCl}_{2} \mathrm{Br}, \mathrm{CH}_{2} \mathrm{Br}_{2}$ and $\mathrm{CHClBr}_{2}$ show the same global pattern as $\mathrm{CH}_{2} \mathrm{ClBr}$. They are scaled by a constant factor yielding the annual global emission fluxes as proposed by Warwick et al. (2006a). These are listed in Table 6. It is assumed that the bromocarbon emissions are highest in the tropics, decrease towards the mid-latitudes and approach zero at high-latitudes $\left(>50^{\circ} \mathrm{N}\right.$ or $\left.\mathrm{S}\right)$. For bromoform, additionally enhanced coastal emissions are assumed which result in a slightly different emission pattern. For methyl bromide pseudo-emissions are calculated using the submodel TNUDGE by prescribing the observed mixing ratio in the lowest model layer by a Newtonian relaxation technique and diagnosing the resulting tendency as pseudo-emission flux. For more detail we refer to Kerkweg et al. (2006b). In case of $\mathrm{CH}_{3} \mathrm{Br}$ the observations from the measurement stations of the ALE/GAGE/AGAGE database (Prinn et al., 2000) and Montzka et al. (2003) are extrapolated into the respective surrounding latitude band yielding monthly zonal averages. Thus, the input data for TNUDGE are specific for each month and year and the trend in the surface $\mathrm{CH}_{3} \mathrm{Br}$ mixing ratios as reported by Montzka et al. (2003) is considered (Fig. 2).

To evaluate the relative importance of photolysis and reaction with $\mathrm{OH}$ for bromocarbon degradation, diagnostic tracers are introduced to trace the yields of $\mathrm{Br}$ radicals by photolysis of the six bromocarbons and by their reactions with $\mathrm{OH}$. The supplement of this article (http://www.atmos-chem-phys.net/8/5919/2008/ acp-8-5919-2008-supplement.zip) comprises a full list of all reactions taken into account in the chemistry mechanism of MECCA (Sander et al., 2005; Kerkweg et al., 2007). The rate coefficients for the reactions of the bromocarbons with OH (Eqs. G7404 to G7408 in the supplement) have been estimated by Yang et al. (2005). Their photolysis rates have been included following the suggestions of Sander et al. (2003).

The simulation period is 3 years (January 1998 to December 2000). The first two years are taken as model spin up, whereas the year 2000 is analysed. Methyl bromide was initialised from the ECHAM5/MESSy S1 simulation (Jöckel et al., 2006). The other initial halocarbon mixing ratios have been scaled to methyl bromide. The two years 
of model spinup are sufficient to ensure that no more artificial trends from the initialisation are present. As chemistry calculations which include gas and aerosol phase reactions are computationally very expensive, simulations of longer periods are not yet feasible. One simulation month took approximately $14 \mathrm{~h}$ wall clock time on 256 CPUs of the IBM pSeries Regatta system, based on Power 4 processor technology at the Rechenzentrum Garching (RZG).

\section{Comparison of bromocarbon distributions}

Bromocarbon observations are scarce because these compounds are difficult to measure and the interest to study them was limited. We concentrate on the comparison with observations in the midlatitudes and tropics, as a meaningful comparison with high-latitude (polar) data would require a model comprising parameterisations for the specific needs of tropospheric polar chemistry in particular for polar ozone depletion events.

Most observations are limited to $\mathrm{CH}_{3} \mathrm{Br}$ and $\mathrm{CHBr}_{3}$. We start with the investigation of the species with the shortest lifetime, $\mathrm{CHBr}_{3}$, followed by the analysis of the distributions of $\mathrm{CH}_{2} \mathrm{Br}_{2}, \mathrm{CH}_{2} \mathrm{ClBr}, \mathrm{CHCl}_{2} \mathrm{Br}$ and $\mathrm{CHClBr}_{2}$. We complete this section with the analysis of methyl bromide, the compound with the longest lifetime of the six investigated bromocarbons.

\section{1 $\mathrm{CHBr}_{3}$}

Bromoform is the shortest-lived bromocarbon addressed here with a lifetime of approximately 3 weeks. Figure 3 presents the simulated annual average surface mixing ratios of bromoform in $\mathrm{pmol} / \mathrm{mol}$ for the year 2000. Measurements of surface $\mathrm{CHBr}_{3}$ are reported more often than for other shortlived bromocarbons (see Table 2).

Surface $\mathrm{CHBr}_{3}$ was measured by Yokouchi et al. (1997) during two western Pacific cruises (one from 31 January 1991, to 20 February 1991, in the area of approximately $135-165^{\circ} \mathrm{E}, 25^{\circ} \mathrm{S}$ to $40^{\circ} \mathrm{N}$; and one from 16 September to 25 October 1992 , in the area of $135-180^{\circ} \mathrm{E}, 40^{\circ} \mathrm{S}$ to $40^{\circ} \mathrm{N}$ ). They report mixing ratios between 0.13 and $2.9 \mathrm{pmol} / \mathrm{mol}$ for the western Pacific cruises. For this region, the $\mathrm{CHBr}_{3}$ mixing ratios in the simulation are higher reaching values between 0.14 and $33 \mathrm{pmol} / \mathrm{mol}$ with an average of $1.9 \mathrm{pmol} / \mathrm{mol}$. The same holds for the Asian cruise with maxima of $7.1 \mathrm{pmol} / \mathrm{mol}$ and $10 \mathrm{pmol} / \mathrm{mol}$ for the observations and the simulation, respectively. Carpenter et al. (1999) observed bromoform at Mace Head, Ireland $\left(53^{\circ} 19^{\prime} \mathrm{N}, 9^{\circ} 54^{\prime} \mathrm{W}\right)$ during May, 1997. The bromoform mixing ratios ranged from 1.9 to $16.3 \mathrm{pmol} / \mathrm{mol}$ with an average of $6.3 \mathrm{pmol} / \mathrm{mol}$. Two factors contribute to these relatively high mixing ratios. First, the biological seasonal cycle induces higher bromoform mixing ratios (Carpenter et al., 2005) during summer (from mid-March to mid-October:

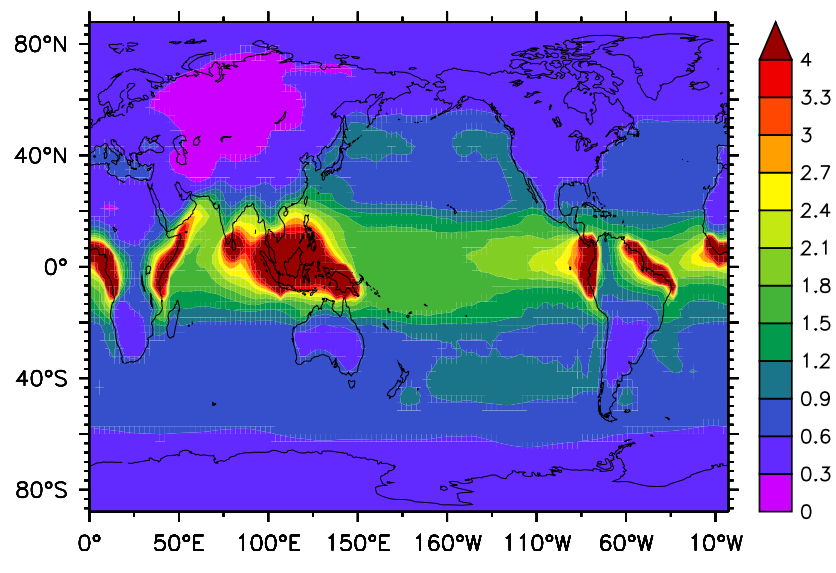

Fig. 3. Simulated annually averaged $\mathrm{CHBr}_{3}$ mixing ratio $(\mathrm{pmol} / \mathrm{mol})$ in the lowest model layer for the year 2000 .

on average $5.3 \mathrm{pmol} / \mathrm{mol}$ ) and lower ones in winter (midOctober to mid-March: on average $1.8 \mathrm{pmol} / \mathrm{mol}$ ). Thus, the mixing ratio measured by Carpenter et al. (1999) is at the high end of what is to be expected in summer at Mace Head. Second, Mace Head is a well-known coastal source region for bromocarbons. Carpenter and Liss (2000) observed bromoform at Mace Head during the PARFORCE campaign (average: $6.8 \mathrm{pmol} / \mathrm{mol} ; 1.0-22.7 \mathrm{pmol} / \mathrm{mol}$ ) and at Cape Grim, Tasmania during SOAPEX 2 (average: $2.6 \mathrm{pmol} / \mathrm{mol}$; $0.6-$ $8.0 \mathrm{pmol} / \mathrm{mol}$; Carpenter et al., 2003). Our simulated surface mixing ratios for this region are near the low end of this range, possibly because of the coarse model resolution as there is no distinction between coastal zones and the open sea. Ramacher et al. (1999) observed bromoform in Ny Ålesund, Norway $\left(78^{\circ} 55^{\prime} \mathrm{N}, 11^{\circ} 56^{\prime} \mathrm{E}\right)$ and report an average of $0.65 \mathrm{pmol} / \mathrm{mol}$. The measurements range from below the detection limit up to $1.0 \mathrm{pmol} / \mathrm{mol}$. Our simulation agrees well with these measurements.

The only available data for a comparison of the vertical profiles are those from the PEM-Tropics A and B campaigns (Emmons et al., 2000; Colman et al., 2001; Blake et al., 2001). Figure 4 shows the simulated vertical profiles for bromoform (black line) compared to the PEMTropics A data (red dots). The figure displays only a small subset of the available data, however, the supplement of this article (http://www.atmos-chem-phys.net/8/5919/2008/ acp-8-5919-2008-supplement.zip) contains a document providing all profiles for all three campaigns. The profiles for the PEM-Tropics B campaign are very similar and not shown here. Since this simulation was performed for the year 2000 only, we show values for this year. The solid line indicates a spatiotemporal average for the respective flight. The dashed lines indicate the simulated minimum and maximum values during the campaign. Near the surface the simulation matches the vertical gradient, i.e. an increase towards the surface in most profiles. In contrast, the upper parts of 

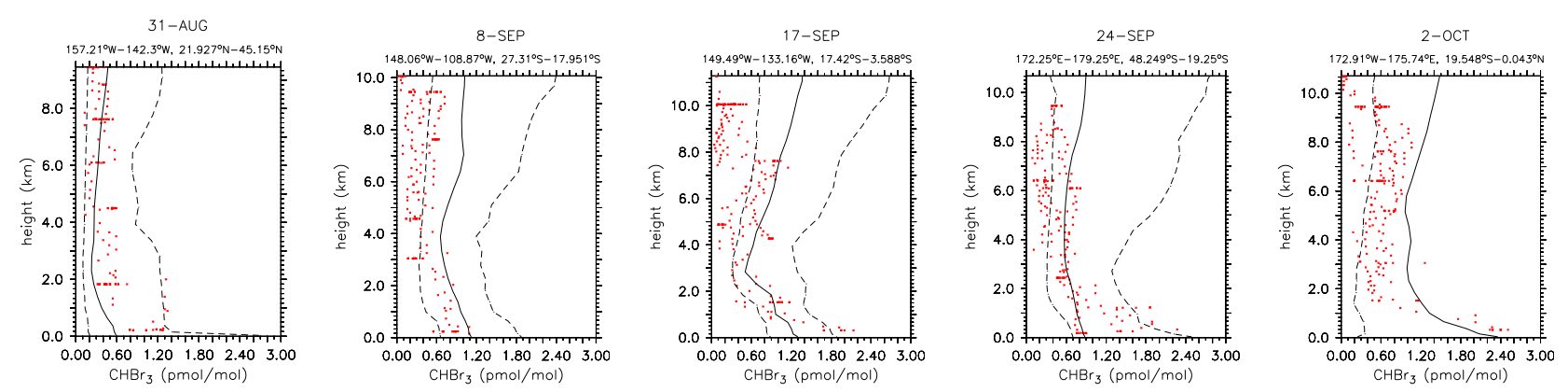

Fig. 4. $\mathrm{CHBr}_{3}$ vertical profiles (pmol/mol) as measured during the PEM-Tropics A DC8 campaign (red dots). The black lines show the simulated vertical profiles averaged over the flight period and area. The dashed lines indicate the simulated minimum and maximum $\mathrm{CHBr}_{3}$ mixing ratios during the whole campaign period.

Table 3. List of surface measurements (average, minimum and maximum) of $\mathrm{CH}_{2} \mathrm{Br}_{2}(\mathrm{pmol} / \mathrm{mol})$ in the mid-latitudes and tropics.

\begin{tabular}{llrrrr}
\hline Reference & Location & Time & mean & $\min$ & $\max$ \\
\hline Penkett et al. (1985) & Atlantic Ocean NH & $1982 / 1983$ & 2.70 & 2.11 & 3.29 \\
& Atlantic/Southern Ocean SH & & 1.58 & 1.32 & 1.84 \\
Class and Ballschmiter (1988) & Atlantic Ocean & 1985 & 2 & 1 & 25 \\
Yokouchi et al. (1997) & Western Pacific 1 & Feb 1991 & 0.87 & 0.47 & 1.36 \\
& Western Pacific 2 & Sept-Oct 1992 & 0.59 & 0.14 & 1.58 \\
& Asian coast & Feb 1994 & 0.77 & 0.38 & 1.42 \\
Carpenter et al. (2003) & Mace Head $^{\text {a }}$ & Sept 1998 & 1.44 & 0.28 & 3.39 \\
& Cape Grim $^{\text {b }}$ & & 0.43 & 0.1 & 1.39 \\
\hline
\end{tabular}

a PARFORCE campaign, ${ }^{b}$ SOAPEX 2 campaign. NH Northern Hemisphere, SH Southern Hemisphere.

the profiles do not match well. The observations mostly decrease towards higher altitudes, whereas most simulated profiles increase towards the tropopause. This is also in contradiction to measurements of the NASA START campaign (Schauffler et al., 1998). During this campaign in JanuaryFebruary, July-August and December 1996 most bromocarbons discussed here were measured in the tropical tropopause region. Schauffler et al. (1998) found bromoform at or below $0.2 \mathrm{pmol} / \mathrm{mol}$ in the upper tropical troposphere. Our simulation reaches values as high as $2 \mathrm{pmol} / \mathrm{mol}$.

Unfortunately, we assumed the wrong rate coefficient for the reaction $\mathrm{CHBr}_{3}+\mathrm{OH}$. We could not redo the whole simulation, as it is much too sumptuous. Since photolysis and reaction with $\mathrm{OH}$ are the only chemical sinks of bromoform, we performed a sensitivity analysis by applying a chemical mechanism reduced to bromoform chemistry only. The $\mathrm{OH}$ concentration was prescribed by monthly means from the main simulation (S-hal; Kerkweg et al., 2008). Using monthly averaged $\mathrm{OH}$ fields must change the bromoform decay in contrast to prognostically calculated $\mathrm{OH}$. Thus we performed this analysis study for the wrong rate as used in the S-hal simulation and for the new rate, which was taken from Sander et al. (2006)
$\left(R_{\mathrm{CHBr}_{3}+\mathrm{OH}}=1.35 \times 10^{-12} * \exp (-600 . / T)\right.$, with $T$ temperature in $\mathrm{K}$ ), to calculate the relative importance of the different rates. Figures 12 and 13 in the supplement display the profiles for the corrected bromoform mixing ratios. In general, the $\mathrm{CHBr}_{3}$ mixing ratios are lower as in the S-hal simulation. They agree well with the observations in the middle troposphere for most profiles. Nevertheless, the shape of the profiles is very similar, i.e. the corrected bromoform still increases towards the tropopause, but this increase is much smaller for most of the profiles compared to the S-hal simulation.

The bromoform mixing ratio in the upper troposphere/lower stratosphere (UTLS) is most probably overstimated for dynamical reasons. A detailed analysis of the vertical velocity fields at all the dates and places of the vertical profiles of PEM-Tropics A showed that all c-shaped profiles are associated with large scale downward motion which is mostly attributed to the Hadley cell circulation. Obviously, this motion transports bromoform downward into the upper to free troposphere. As the only source of bromoform is emission at the surface, it must have been transported upward by convection, i.e. in the upward branch of the Hadley cell circulation. Thus convection plays an important role 
for the simulated overestimation in the upper troposphere. But the convection scheme by Tiedtke does not overestimate neither convection intensity or height, nor the frequence at which convection is triggered (Tost et al., 2006b). Hence, the bromoform emission in the tropics which have been increased along the coastlines by Warwick et al. (2006a) to yield a better agreement between their simulation and the observations are most probably too high. Thus too much bromoform is transported upward by convection resulting in too high bromoform mixing ratios in the subsidence area of the Hadley cell. This is confirmed by the good agreement of the measured and the simulated profiles (the corrected ones) in the lower and middle troposphere in all regions which recently have been subject to convection. These regions can be identified by their flat profiles.

\section{$3.2 \mathrm{CH}_{2} \mathrm{Br}_{2}$}

The number of measurements for dibromomethane is very limited. Measurements at the surface in the mid-latitudes and tropics are listed in Table 3. Figure 5 displays the simulated annually averaged surface mixing ratios of $\mathrm{CH}_{2} \mathrm{Br}_{2}$. For the Atlantic Ocean the simulation underestimates the $\mathrm{CH}_{2} \mathrm{Br}_{2}$ abundance ranging only from 0.8 to $2 \mathrm{pmol} / \mathrm{mol}$, whereas both observers (Penkett et al., 1985; Class and Ballschmiter, 1988) report mixing ratios ranging from 1.32 to $3.29 \mathrm{pmol} / \mathrm{mol}$ with an average above $2 \mathrm{pmol} / \mathrm{mol}$. This underestimation is also present in comparison to the observations reported by Carpenter et al. (2003). They report $\mathrm{CH}_{2} \mathrm{Br}_{2}$ mixing ratios ranging from 0.28 to $3.39 \mathrm{pmol} / \mathrm{mol}$ with an average of $1.44 \mathrm{pmol} / \mathrm{mol}$ at Mace Head during the PARFORCE campaign (September 1998). This is about a factor of 2 more $\mathrm{CH}_{2} \mathrm{Br}_{2}$ than predicted by the simulation. This discrepancy may be partly attributed to the local effects, as Mace Head is located directly at the shore. This is likely to give higher mixing ratios than the average for a model gridbox of $\approx 250 \mathrm{~km}$ length. In contrast, the simulation agrees well with the range reported by Penkett et al. (1985) for the southern Ocean and those reported by Yokouchi et al. (1997) for the western Pacific and the Asian coast, whereas the surface mixing ratios measured during the SOAPEX 2 campaign (Carpenter et al., 2003) are slightly overestimated by the simulation.

To evaluate the vertical distribution of $\mathrm{CH}_{2} \mathrm{Br}_{2}$ aircraft measurements are required. The aircraft measurement campaigns PEM-Tropics A and B (Colman et al., 2001) and the project CARIBIC provide the only available databases for $\mathrm{CH}_{2} \mathrm{Br}_{2}$ measurements. Colman et al. (2001) observed $\mathrm{CH}_{2} \mathrm{Br}_{2}$ mixing ratios from 0.41 to $2.55 \mathrm{pmol} / \mathrm{mol}$ for the PEM-Tropics A campaign. Figure 6 shows the vertical profiles of $\mathrm{CH}_{2} \mathrm{Br}_{2}$ mixing ratios for the PEM-Tropics $\mathrm{B}$ campaign. The simulation overestimates $\mathrm{CH}_{2} \mathrm{Br}_{2}$ in all profiles. The observations are mostly below the interval determined by the minimum and maximum values in the model for the whole period of the measurement campaign. Nevertheless,

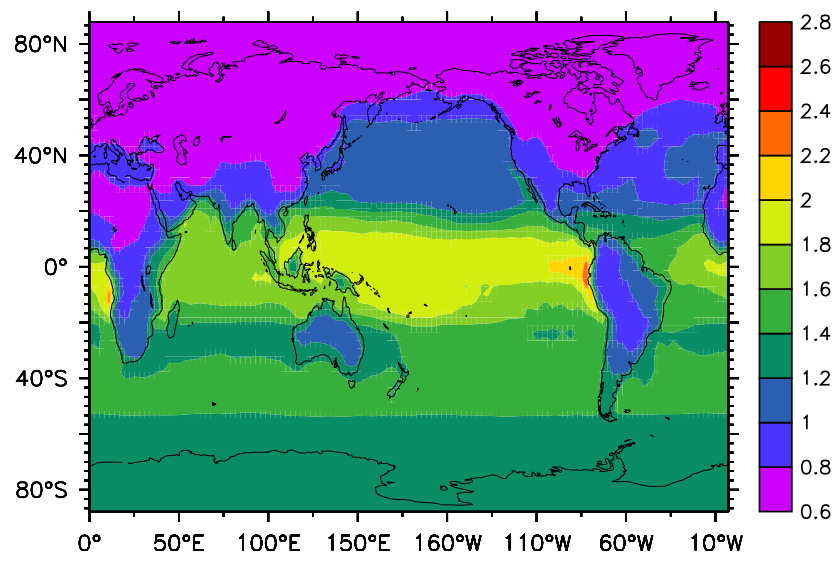

Fig. 5. Simulated annual average $\mathrm{CH}_{2} \mathrm{Br}_{2}$ in $\mathrm{pmol} / \mathrm{mol}$ in the lowest model layer.

the mixing ratios usually increase towards the surface in the simulation and in the measurements. The comparison of the vertical profiles to the PEM-Tropics A data is similar and therefore not shown here, but it is available in the supplement.

The second collection of $\mathrm{CH}_{2} \mathrm{Br}_{2}$ aircraft measurements used is from the CARIBIC1 database (Oram et al., 2008; Brenninkmeijer et al., 1999). Figure 7 shows the comparison of the simulation (black line) with the CARIBIC1 data (red line) for eight flights in 2000. The simulation overestimates the amount of $\mathrm{CH}_{2} \mathrm{Br}_{2}$ at cruising altitude $(\approx 9-$ $11 \mathrm{~km}$ ) by a factor of approximately 1.5 . As a consequence of the rather coarse horizontal resolution of the model setup, the variability in time is smaller in all simulations compared to the observations, partly also because averaging over the model grid-boxes smoothes small scale variations.

In addition to these aircraft observations for which the data can be used for a direct comparison, some measurement data are available in the literature. Schauffler et al. (1993) measured a range of 0.15 to $1.02 \mathrm{pmol} / \mathrm{mol}$, with an average of $0.72 \mathrm{pmol} / \mathrm{mol}$ during the AASE-II campaign (1991/1992) at a flight altitude from 15.3 to $17.2 \mathrm{~km}$. For the same area, the model predicts $\mathrm{CH}_{2} \mathrm{Br}_{2}$ mixing ratios of about $0.55 \mathrm{pmol} / \mathrm{mol}$ with a range from 0.11 to $0.9 \mathrm{pmol} / \mathrm{mol}$. This matches the measurements by Schauffler et al. (1993), even though the average is too low. Kourtidis et al. (1996) published three coarse vertical profiles of $\mathrm{CH}_{2} \mathrm{Br}_{2}$. One was measured over Hyderabad, India $\left(17.5^{\circ} \mathrm{N}\right)$ on 9 April 1990, the others were measured over Kiruna, Sweden $\left(68^{\circ} \mathrm{N}\right)$. For Hyderabad the shape of the model profile matches the observations relatively well, but the absolute values are too high. Apart from one low value at $10 \mathrm{~km}$ altitude, the gradient at the tropopause is relatively well captured. For the observations at Kiruna the simulated mixing ratios are lower by less than a factor of 2 for January for the measurements above the detection limit. For March, the simulation is off by a factor of 

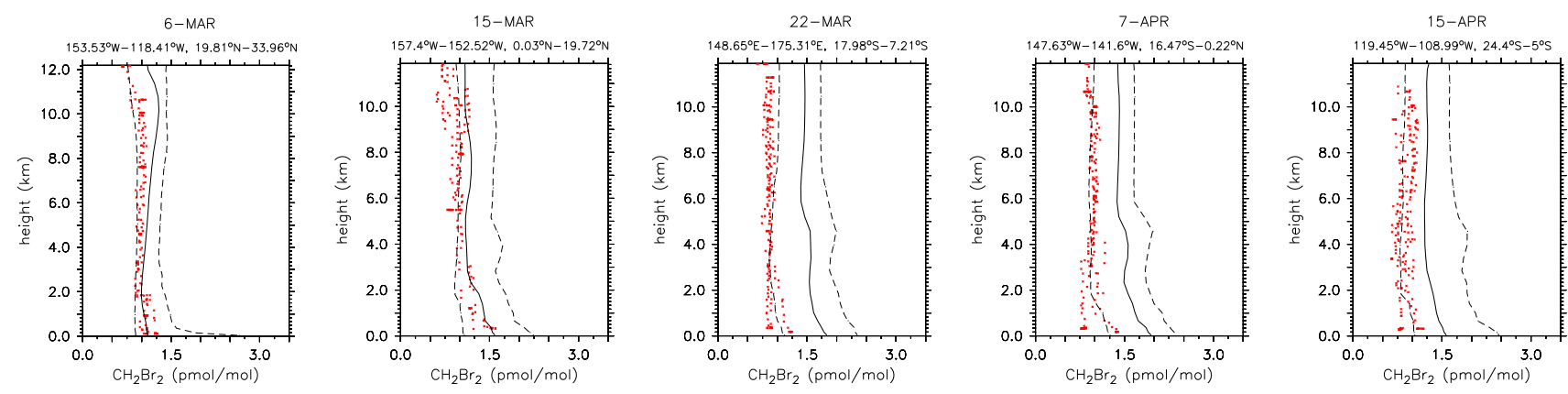

Fig. 6. As Fig. 4 but for $\mathrm{CH}_{2} \mathrm{Br}_{2}$ and the PEM-Tropics $\mathrm{B}$ campaign.
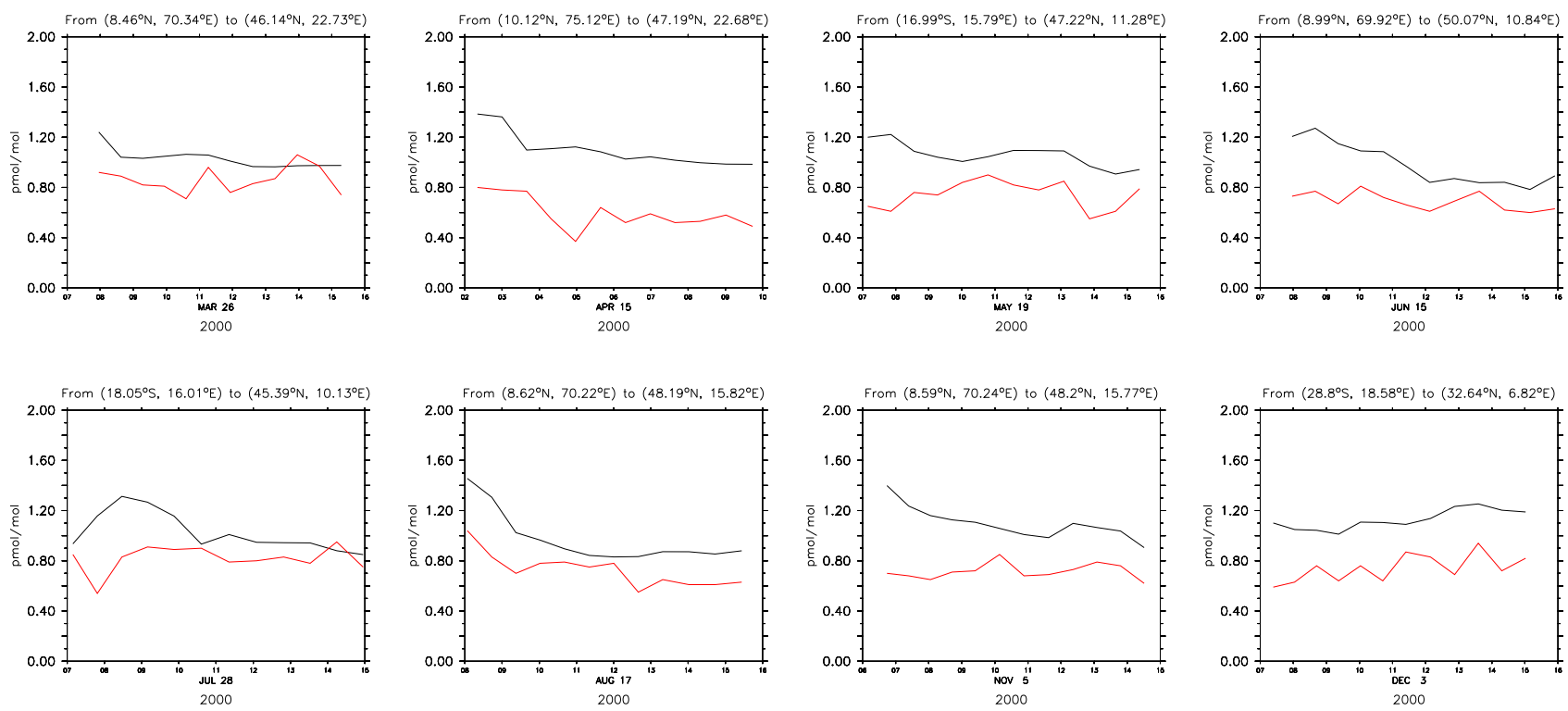

Fig. 7. Point to point comparison of $\mathrm{CH}_{2} \mathrm{Br}_{2}$ mixing ratios from the CARIBIC aircraft data (red line) and model results (black) as a function of hour of day (UTC) from March-December 2000.

2. The steep gradient in the measurements is also found in the simulation, though at a higher altitude. This might be due to the offset of the tropopause height of the model $(\approx 9 \mathrm{~km})$ compared to the observed tropopause height of $7.2 \mathrm{~km}$.

Figure 8 shows the seasonal cycle of the vertical distribution of $\mathrm{CH}_{2} \mathrm{Br}_{2}$. The $\mathrm{CH}_{2} \mathrm{Br}_{2}$ concentrations are highest in the Southern Hemisphere. The mixing ratio decrease in the northern summer hemisphere is much more pronounced than in the Southern Hemisphere. This is due to the distribution of the sources and sinks of $\mathrm{CH}_{2} \mathrm{Br}_{2}$. First, the emission fluxes of $\mathrm{CH}_{2} \mathrm{Br}_{2}$ are assumed to be only oceanic and symmetric around the Equator. Since a larger part of the Southern Hemisphere is covered by the ocean, the total emissions are larger. Second, the losses by photolysis and reaction with $\mathrm{OH}$ give rise to a seasonal cycle. The zonally averaged vertical distributions of $\mathrm{OH}$ concentrations in $10^{6} / \mathrm{cm}^{3}$ are given in Fig. 9. The concentration of $\mathrm{OH}$ is higher in the north- ern hemispheric summer than in the southern hemispheric summer, thus the oxidation of $\mathrm{CH}_{2} \mathrm{Br}_{2}$ by $\mathrm{OH}$ is stronger in the Northern Hemisphere. Schauffler et al. (1998) measured on average $0.5( \pm 0.2) \mathrm{pmol} / \mathrm{mol}$ in the tropical tropopause region. Figure 8 suggests that the model overestimates this mixing ratio by a factor of 2 , depending on the position of the tropopause, here indicated by the black line. Shown is the average position for this time interval.

\section{$3.3 \mathrm{CHClBr}_{2}, \mathrm{CHCl}_{2} \mathrm{Br}$ and $\mathrm{CH}_{2} \mathrm{ClBr}$}

Knowledge about these short-lived bromocarbons is sparse. Therefore, their emissions were scaled to the oceanic bromoform emissions according to the estimated global annual emission flux (see Table 6) as proposed by Warwick et al. (2006a). These species have been mostly investigated in high-latitudinal (polar) regions (Sturges et al., 2001; Yok- 

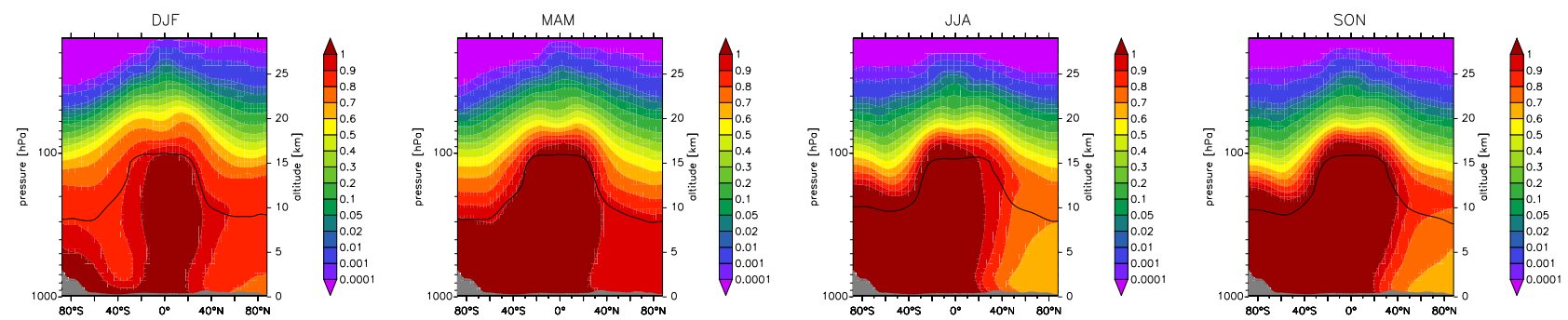

Fig. 8. Simulated vertical distribution of $\mathrm{CH}_{2} \mathrm{Br}_{2}$ in pmol/mol. Shown are seasonal averages; DJF: December 1999, January 2000, February 2000; MAM: March-May 2000; JJA: June-August 2000; SON: September-November 2000.
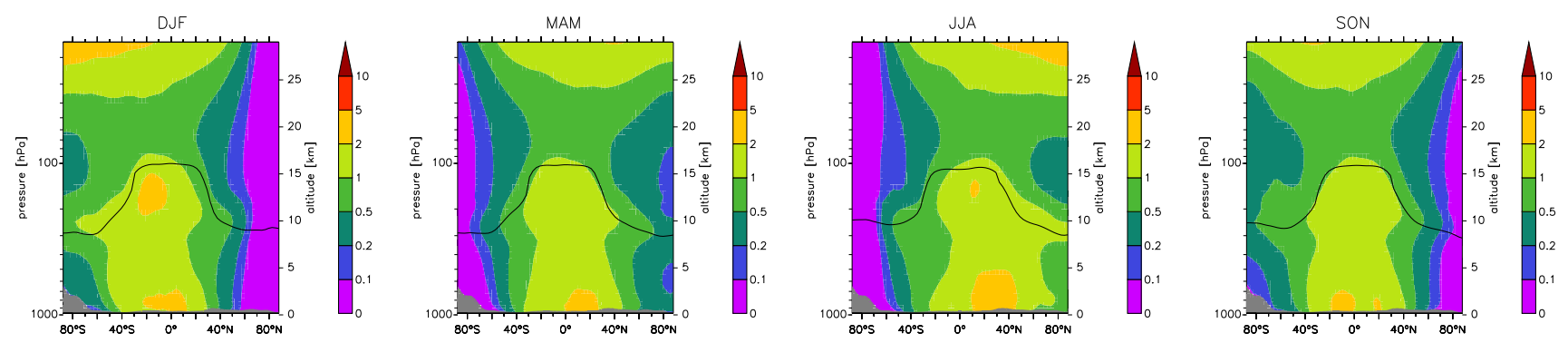

Fig. 9. Simulated vertical distribution of $\mathrm{OH}$ in $10^{6} / \mathrm{cm}^{3}$. Seasons as in Fig. 8 .

ouchi et al., 1996; Simpson et al., 2007). Our model does not include any parameterisation of the processes leading to polar ozone depletion events. Thus, a comparison with these data is not feasible.

Table 4 lists the few available surface measurements for $\mathrm{CHClBr}_{2}, \mathrm{CHCl}_{2} \mathrm{Br}$ and $\mathrm{CH}_{2} \mathrm{ClBr}$. Carpenter et al. (1999) report $\mathrm{CHClBr}_{2}$ mixing ratios from 0.3 to $1.8 \mathrm{pmol} / \mathrm{mol}$ with an average of $0.8 \mathrm{pmol} / \mathrm{mol}$ for Mace Head, Ireland, whereas Schall and Heumann (1993) observed from $<0.01$ to $1.0 \mathrm{pmol} / \mathrm{mol}$ in Spitsbergen, Norway, with an average of $0.33 \mathrm{pmol} / \mathrm{mol}$ and Class and Ballschmiter (1988) found on average $0.3 \mathrm{pmol} / \mathrm{mol}$ over the Atlantic Ocean with mixing ratios varying from 0.1 to $5 \mathrm{pmol} / \mathrm{mol}$. The left panel of Fig. 10 presents the simulated annual average surface mixing ratios of $\mathrm{CHClBr}_{2}$. The simulation agrees with the observations fairly well. For the mid-latitudes and tropics the surface measurements reported by Class and Ballschmiter (1988) are - to our knowledge - the only available for $\mathrm{CHCl}_{2} \mathrm{Br}$ and $\mathrm{CH}_{2} \mathrm{ClBr}$. The simulated surface mixing ratios (in pmol/mol) are shown in the middle and right panels of Fig. 10, respectively. The abundance of both species is underestimated in the simulation. However, as the information regarding the emissions is equally poor as the number of measurements, no final conclusion can be drawn from this comparison.

Figure 11 shows the seasonal cycle of the vertical distributions (in fmol/mol) of $\mathrm{CHClBr}_{2}$ (top), $\mathrm{CHCl}_{2} \mathrm{Br}$ (middle) and $\mathrm{CH}_{2} \mathrm{ClBr}$ (bottom). The southern hemispheric mixing ratios of all three bromocarbons are higher than the northern hemispheric ones except for DJF. The gradient is largest during the northern hemispheric summer. Generally, due to the higher irradiation the photolysis rates and the $\mathrm{OH}$ concentration are higher in summer leading to a higher rate of decomposition of the bromocarbons. During the STRAT campaign Schauffler et al. (1998) measured $\mathrm{CHClBr}_{2}, \mathrm{CHCl}_{2} \mathrm{Br}$ and $\mathrm{CH}_{2} \mathrm{ClBr}$ mixing ratios at the tropical tropopause of about 40, 20 and $120 \mathrm{fmol} / \mathrm{mol}$, respectively. These values are for $\mathrm{CHClBr}_{2}$ and $\mathrm{CH}_{2} \mathrm{ClBr}$ in general agreement with the average mixing ratios as shown in Fig. 11, whereas the $\mathrm{CHCl}_{2} \mathrm{Br}$ mixing ratio at the tropical tropopause is up to a factor of 3 larger than measured by Schauffler et al. (1998).

The only available vertical profiles from aircraft measurements for these three compounds are from the PEMTropics A and B campaigns (Emmons et al., 2000; Colman et al., 2001; Blake et al., 2001). Figure 12 presents the vertical profiles for $\mathrm{CHClBr}_{2}$ measured during the PEMTropics B campaign. The observations and the simulation agree well. The picture for the PEM-Tropics A campaign is very similar and thus not shown here. Figures 13 and 14 show a comparison of the observed and simulated $\mathrm{CHCl}_{2} \mathrm{Br}$ vertical profiles during PEM-Tropics A and PEM-Tropics B, respectively. For PEM-Tropics $\mathrm{B}$ the model underestimates the $\mathrm{CHCl}_{2} \mathrm{Br}$ mixing ratios, whereas for PEM-Tropics $\mathrm{A}$ they are slightly overestimated. The model tends to simulate increasing mixing ratios towards the surface, which is 


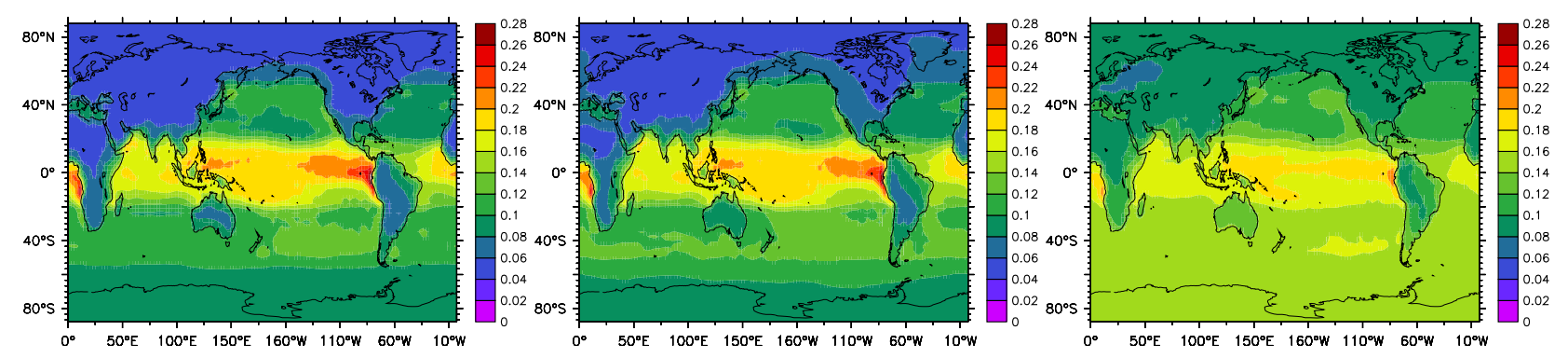

Fig. 10. Annual average $\mathrm{CHClBr}_{2}$ (left), $\mathrm{CHCl}_{2} \mathrm{Br}$ (middle) and $\mathrm{CH}_{2} \mathrm{ClBr}$ (right) in the lowest model layer in pmol/mol.

Table 4. List of surface measurements (average, minimum and maximum) of $\mathrm{CHClBr}_{2}, \mathrm{CHCl}_{2} \mathrm{Br}$ and $\mathrm{CH}_{2} \mathrm{ClBr}(\mathrm{pmol} / \mathrm{mol}$ ) in the midlatitudes and tropics.

\begin{tabular}{llcrrr}
\hline Reference & Location & Time & mean & min & max \\
\hline $\mathrm{CHClBr}_{2}$ & & & & & \\
Class and Ballschmiter (1988) & Atlantic Ocean & 1985 & 0.3 & 0.1 & 5 \\
Schall and Heumann (1993) & Spitsbergen & $09 / 1992$ & 0.33 & $<0.01$ & 1.0 \\
Carpenter et al. (1999) & Mace Head & May 1997 & 0.8 & 0.3 & 1.8 \\
\hline $\mathrm{CHCl}_{2} \mathrm{Br}$ & & & & & \\
$\mathrm{Class}$ and Ballschmiter (1988) & Atlantic Ocean & 1985 & 0.3 & 0.2 & 1 \\
\hline $\mathrm{CH}_{2} \mathrm{ClBr}$ & & & & & \\
$\mathrm{Class}$ and Ballschmiter (1988) & Atlantic Ocean & 1985 & 0.4 & 0.2 & 0.4 \\
\hline
\end{tabular}

not always evident in the observations. $\mathrm{CH}_{2} \mathrm{ClBr}$ measurements are only available for PEM-Tropics B (Fig. 15). The simulation underestimates the $\mathrm{CH}_{2} \mathrm{ClBr}$ mixing ratio by up to a factor of 2. At the beginning and the end of the PEMTropics $\mathrm{B}$ campaign the observed mixing ratios of $\mathrm{CH}_{2} \mathrm{ClBr}$ and $\mathrm{CHCl}_{2} \mathrm{Br}$ are very high. The feature is not covered by the simulation indicating a so far unknown source process of $\mathrm{CH}_{2} \mathrm{ClBr}$ and $\mathrm{CHCl}_{2} \mathrm{Br}$.

In general, no systematic model biases are apparent from Figs. 12-15 and the observations are well captured. Some of the model-measurement discrepancies may be attributed to the simplified emission distribution of $\mathrm{CHClBr}_{2}, \mathrm{CHCl}_{2} \mathrm{Br}$ and $\mathrm{CH}_{2} \mathrm{ClBr}$ rather than to their overall emission strength.

\section{$3.4 \mathrm{CH}_{3} \mathrm{Br}$}

Methyl bromide is the longest-lived species of all six bromocarbons investigated here, and relatively many measurement data are available (Table 5). Andreae et al. (1996) measured 10 to $60 \mathrm{pmol} / \mathrm{mol}$ of methyl bromide in air influenced by forest fires. This may be considered as an upper limit as methyl bromide is enhanced in biomass burning plumes. At Mace Head Carpenter et al. (1999) observed a mean methyl bromide mixing ratio of
$13.9 \mathrm{pmol} / \mathrm{mol}$, with a range from 9.3 to $26.1 \mathrm{pmol} / \mathrm{mol}$. Since the coastal region near Mace Head is known to be a strong source of bromocarbons, these mixing ratios probably also represent upper limits for methyl bromide. Similar values - also measured in coastal regions - i.e. a mean of $13.7 \mathrm{pmol} / \mathrm{mol}(10.6-17 \mathrm{pmol} / \mathrm{mol})$, are reported by Ramacher et al. (1999) for Ny Ålesund. Gros et al. (2003) measured $12( \pm 3) \mathrm{pmol} / \mathrm{mol}$ in Finokalia $\left(35^{\circ} 19^{\prime} \mathrm{N} 25^{\circ} 40^{\prime} \mathrm{E}\right)$ during the MINOS campaign. Simmonds et al. (2004) observed mixing ratios of $10.37( \pm 0.05) \mathrm{pmol} / \mathrm{mol}$ methyl bromide at Mace Head and considerably lower mixing ratios with a mean of $7.94( \pm 0.03) \mathrm{pmol} / \mathrm{mol}$ at Cape Grim, Tasmania $\left(41^{\circ} \mathrm{S}, 145^{\circ} \mathrm{E}\right)$. This is in accordance with the simulation. The surface mixing ratios of $\mathrm{CH}_{3} \mathrm{Br}$ displayed in Fig. 16 also show a distinct north-south gradient. These measurements are all taken in coastal regions, thus a distinct influence of the tidal forcing on bromocarbon emissions (due to algae falling dry during low tide) is likely: Algae experience oxidative stress when seaweeds are exposed to air at low water (Carpenter et al., 1999).

Montzka et al. (2003) observed a decrease of methyl bromide since 1998 on the basis of ten globally distributed baseline stations. Most of this decline can be attributed to reduced industrial production due to the Montreal Protocol United 

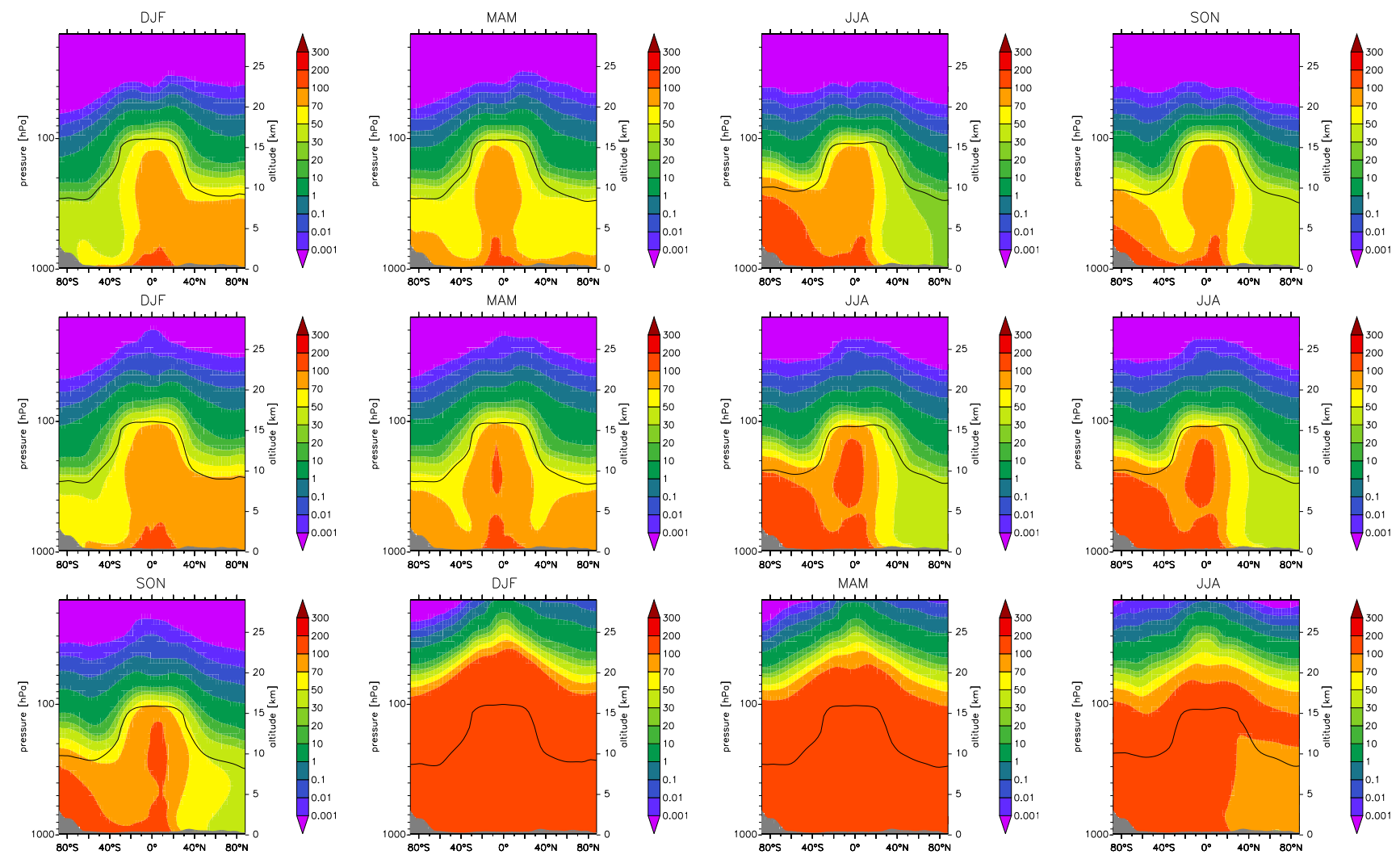

Fig. 11. Simulated vertical distribution of $\mathrm{CHClBr}_{2}$ (upper row), $\mathrm{CHCl}_{2} \mathrm{Br}$ (middle row) and $\mathrm{CH}_{2} \mathrm{ClBr}$ (lower row) in fmol/mol. Shown are seasonal averages from left to right; DJF: December 1999-February 2000; MAM: March-May 2000; JJA: June-August 2000; SON: September-November 2000.
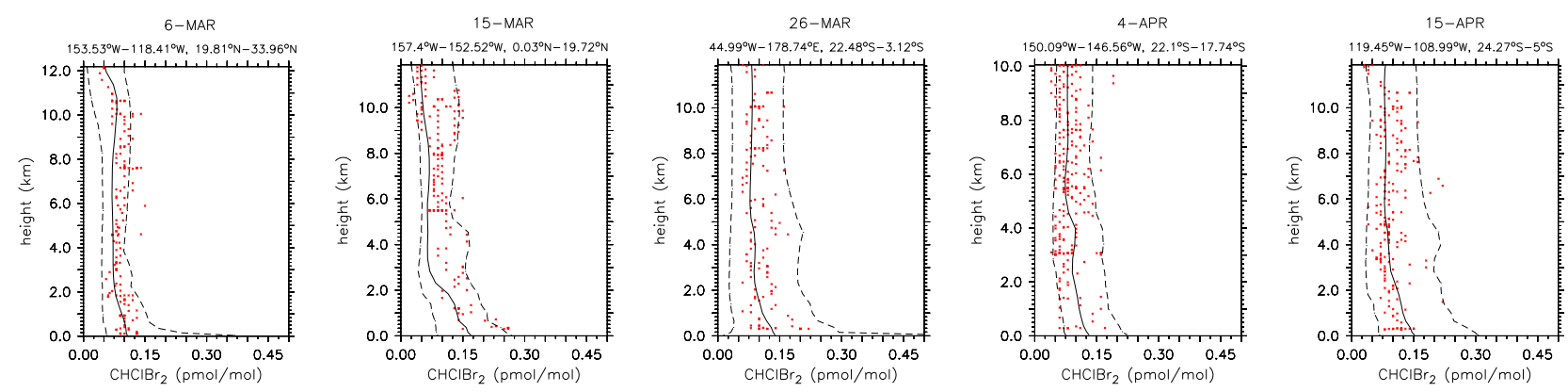

Fig. 12. As Fig. 4 but for $\mathrm{CHClBr}_{2}$ and the PEM-Tropics B campaign.

Nations Environment Programme (UNEP). From their measurements a decrease of the methyl bromide mixing ratios from $\approx 10.5 \mathrm{pmol} / \mathrm{mol}$ for 1998 to $9 \mathrm{pmol} / \mathrm{mol}$ in $2003 \mathrm{can}$ be inferred in the Northern Hemisphere. The mixing ratio of methyl bromide is lower in the Southern Hemisphere, decreasing from $\approx 8.2 \mathrm{pmol} / \mathrm{mol}$ in 1998 to $\approx 7 \mathrm{pmol} / \mathrm{mol}$ in 2003. Montzka et al. (2003) conclude from the fact that the measured decrease of $\mathrm{CH}_{3} \mathrm{Br}$ is larger as the reported indus- trial reduction, that the atmospheric lifetime of methyl bromide is most likely larger ( $\geq 0.8 \mathrm{yr})$ as assumed until now (0.7 yr).

Figure 17 presents the annual average $\mathrm{CH}_{3} \mathrm{Br}$ pseudoemission fluxes resulting from the tracer nudging (see Kerkweg et al., 2006b for a description of the tracer nudging technique). The globally integrated emission fluxes as proposed by Warwick et al. (2006a) and as derived from our model 

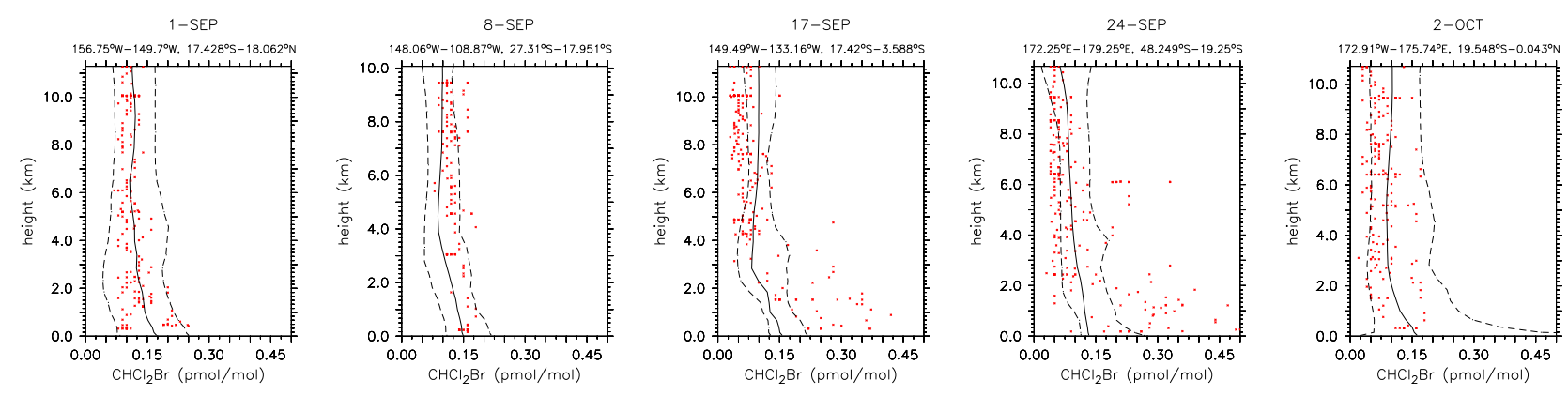

Fig. 13. As Fig. 4 but for $\mathrm{CHCl}_{2} \mathrm{Br}$.
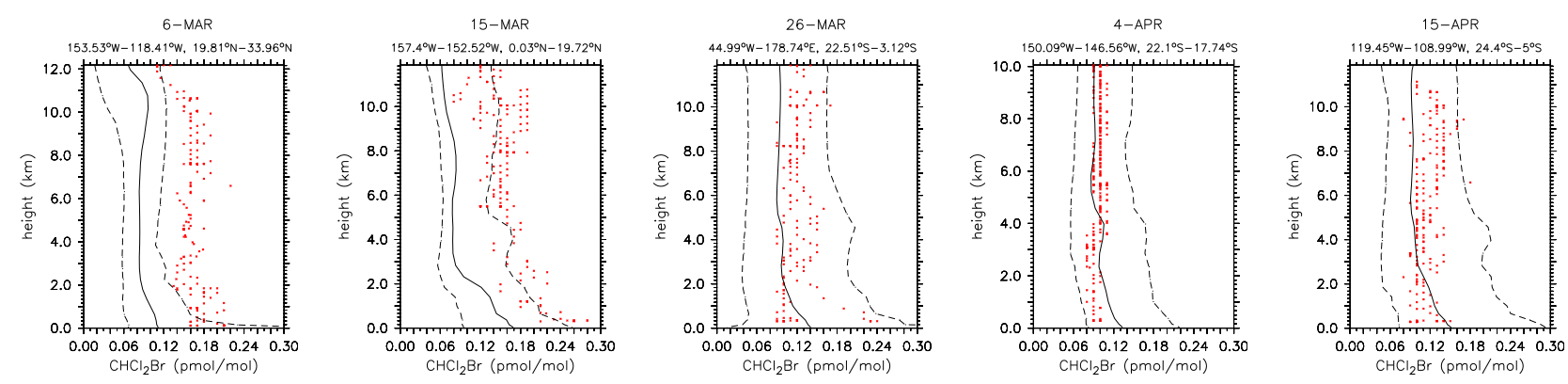

Fig. 14. As Fig. 4 but for $\mathrm{CHCl}_{2} \mathrm{Br}$ and PEM-Tropics $\mathrm{B}$.

simulation do not differ much $(131 \mathrm{Gg} / \mathrm{yr}$ vs. $130.6 \mathrm{Gg} / \mathrm{yr})$. However, the spatial distribution of the emission fluxes of these two parameterisations deviate. In our approach, the methyl bromide mixing ratios are relaxed to the observations. As the used observed field (see Fig. 2) is divided into latitudinal bands, the simulated pseudo-emission flux shows artifical maxima at the border between two bands. However, the tracer nudging method leads to accordance with the observed surface mixing ratios and to consistent methyl bromide concentrations in the stratosphere in longer term simulations (Jöckel et al., 2006). Thus it is reasonable to use this emission approach.

For higher altitudes only data from the aircraft campaigns PEM-West B (Blake et al., 1997), PEM-Tropics A and B (Colman et al., 2001; Blake et al., 2001; Emmons et al., 2000), STRAT (Schauffler et al., 1998), GABRIEL (Gebhardt et al., 2008) and CARIBIC (Brenninkmeijer et al., 1999) are available.

Schauffler et al. (1998) report an average of $9.45 \mathrm{pmol} / \mathrm{mol}$ and Colman et al. (2001) summarise measurements from the PEM-Tropics A (5 August to 6 October 1996) and PEM-Tropics B (6 March to 18 April 1999) campaigns. Mixing ratios of $\mathrm{CH}_{3} \mathrm{Br}$ from 6.0 to $11.9 \mathrm{pmol} / \mathrm{mol}$ were observed, with averages of $8.9 \mathrm{pmol} / \mathrm{mol}$ and $8.6 \mathrm{pmol} / \mathrm{mol}$ for PEM-Tropics A and PEM-Tropics B, respectively. Figure 18 shows the simulated zonally averaged vertical methyl bromide distribution for the campaign periods of PEM-
Tropics A and B though for the year 2000. The simulated mixing ratios compare well to the observations of Colman et al. (2001) and Schauffler et al. (1998). For a more detailed comparison Fig. 19 shows the vertical profiles as measured during the PEM-Tropics B campaign (red dots) and those resulting from the simulation (black lines). For the PEM-Tropics campaigns the simulation and the observations match very well. The vertical profiles for PEM-Tropics A are very similar and the interested reader is referred to the supplement.

The correspondence between simulations and observations decreases towards the north of the measurement domain. This indicates a lack in the representativeness for these positions in the mid-latitudes as zonal averages are used as input. Figure 20 shows the vertical profiles for PEM-West B. The mixing ratios are often underestimated by the model, while the shape of the profiles is reproduced. Part of the discrepancies may be explained by the negative $\mathrm{CH}_{3} \mathrm{Br}$ trend of about 10\% between 1994 (PEM-West B measurements) and 2000 due to a reduction in anthropogenic emissions (WMO, 2007; Montzka et al., 2003).

However, some underestimation of the $\mathrm{CH}_{3} \mathrm{Br}$ abundance is also apparent from the comparison with CARIBIC (Brenninkmeijer et al., 1999) as well as with GABRIEL (Gebhardt et al., 2008) data. Figure 21 displays 8 CARIBIC flights of the year 2000 and Fig. 22 shows the 7 GABRIEL flights, where the measurements of October 2005 are compared to 

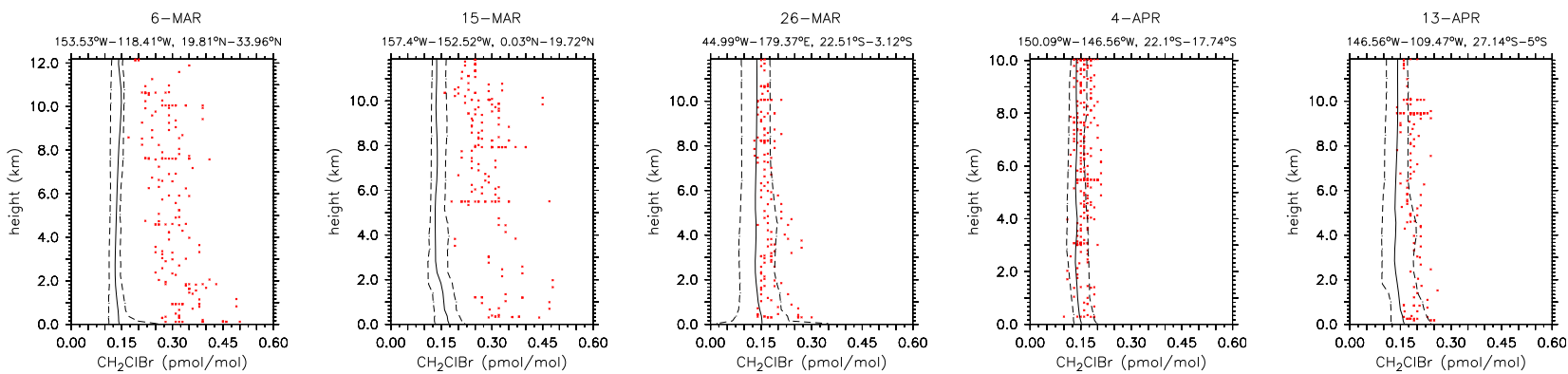

Fig. 15. As Fig. 4 but for $\mathrm{CH}_{2} \mathrm{ClBr}$ and PEM-Tropics B.

Table 5. List of surface measurements (average, minimum and maximum) of $\mathrm{CH}_{3} \mathrm{Br}(\mathrm{pmol} / \mathrm{mol}$ ) in the mid-latitudes and tropics.

\begin{tabular}{llcrrr}
\hline Reference & Location & Time & mean & $\min$ & $\max$ \\
\hline Penkett et al. (1985) & Atlantic Ocean NH & $1982 / 1983$ & 15.4 & 13.5 & 17.3 \\
& Atlantic/Southern Ocean SH & & 10.6 & 9.7 & 11.5 \\
Carpenter et al. (1999) & Mace Head & May 1997 & 13.9 & 9.3 & 26.1 \\
Ramacher et al. (1999) & Ny Ålesund & $\approx$ Apr-May 1996 & 13.7 & 10.6 & 17 \\
Gros et al. (2003) & Crete & Aug 2001 & 12 & 15 & 9 \\
Simmonds et al. (2004) & Mace Head & $1998-2001$ & 10.37 & 10.28 & 10.42 \\
& Cape Grim & & 7.94 & 7.97 & 7.91 \\
Montzka et al. (2003) & 10 baseline stations & 1998 & $\approx 10.5$ & & \\
& & 2003 & $\approx 9.0$ & & \\
\hline
\end{tabular}

${ }^{\mathrm{c}}$ MINOS campaign. NH Northern Hemisphere, SH Southern Hemisphere.

the simulation results of October 2000. The red line indicates the measurements, the black line shows the simulation results, respectively. For most flights the simulation yields too low $\mathrm{CH}_{3} \mathrm{Br}$ mixing ratios. The methane lifetime in our simulation is 7.8 years. This is slightly lower as Jöckel et al. (2006) derived (8.02 years) and well within the range of other models ( $8.67 \pm 1.32$; Stevenson et al., 2006). Thus chemistry is not the reason for the low $\mathrm{CH}_{3} \mathrm{Br}$ mixing ratios. They are most likely a consequence of a lack in representativeness of the methyl bromide source for which latitudinal averages are used. This is probably most relevant for the GABRIEL campaign as $\mathrm{CH}_{3} \mathrm{Br}$ emissions of the tropical rainforest are not explicitly taken into account in our emission inventories. The derived lifetime of $\mathrm{CH}_{3} \mathrm{Br}$ of about a year (Table 6), is up to $50 \%$ larger than previous estimates (WMO (2007), Table 8-2). This helps to reduce an imbalance between estimated sources and sinks (Reeves, 2003). One consequence is that substantially more $\mathrm{CH}_{3} \mathrm{Br}$ may enter the stratosphere and contribute to ozone loss than previously assumed, both presently and in the natural pre-industrial atmosphere.

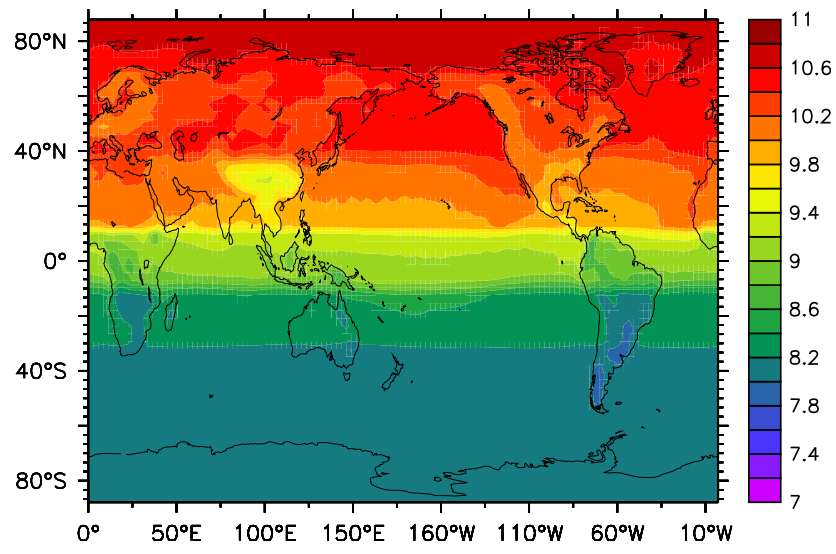

Fig. 16. Annual average (year 2000) of $\mathrm{CH}_{3} \mathrm{Br}(\mathrm{pmol} / \mathrm{mol})$ in the lowest model layer.

\section{Bromocarbons as sources of reactive bromine}

Subsequently to the evaluation of the individual bromocarbon distributions, we focus on the production of reactive bromine by photolysis of bromocarbons and their reactions with $\mathrm{OH}$ and the relative importance of the two pathways. In the following, the term "organic bromine" 
Table 6. Simulated annually averaged global column burdens, annually integrated emission and dry deposition fluxes, and annually averaged lifetimes of the six bromocarbons. The emission fluxes are adopted from Warwick et al. (2006a), scenario 5. The WMO lifetimes are taken from WMO (2007) Tables 8-2 for $\mathrm{CH}_{3} \mathrm{Br}$ and Tables 2-1 for the other bromocarbons.

\begin{tabular}{lrrrrr}
\hline species & burden $(\mathrm{Gg})$ & emission $(\mathrm{Gg} / \mathrm{yr})$ & dry deposition $(\mathrm{Gg} / \mathrm{yr})$ & life time (days) & WMO lifetime (days) \\
\hline $\mathrm{CH}_{3} \mathrm{Br}$ & 136.1 & 130.6 & 46.1 & 386 & 255 \\
$\mathrm{CHBr}_{3}$ & 33.2 & 595.0 & 30.2 & 20 & $26^{*}$ \\
$\mathrm{CH}_{2} \mathrm{Br} 2$ & 31.0 & 113.0 & 12.1 & 100 & $120^{*}$ \\
$\mathrm{CH}_{2} \mathrm{ClBr}$ & 2.8 & 6.8 & 1.0 & 150 & $150^{*}$ \\
$\mathrm{CHCl}_{2} \mathrm{Br}$ & 2.1 & 16.0 & 0.7 & 48 & $78^{*}$ \\
$\mathrm{CHClBr}_{2}$ & 2.3 & 23.0 & 1.1 & 36.5 & $69^{*}$ \\
\hline
\end{tabular}

* These lifetimes are local lifetimes as stated by WMO (2007) Tables 2-1, i.e. not directly comparable to our lifetimes.

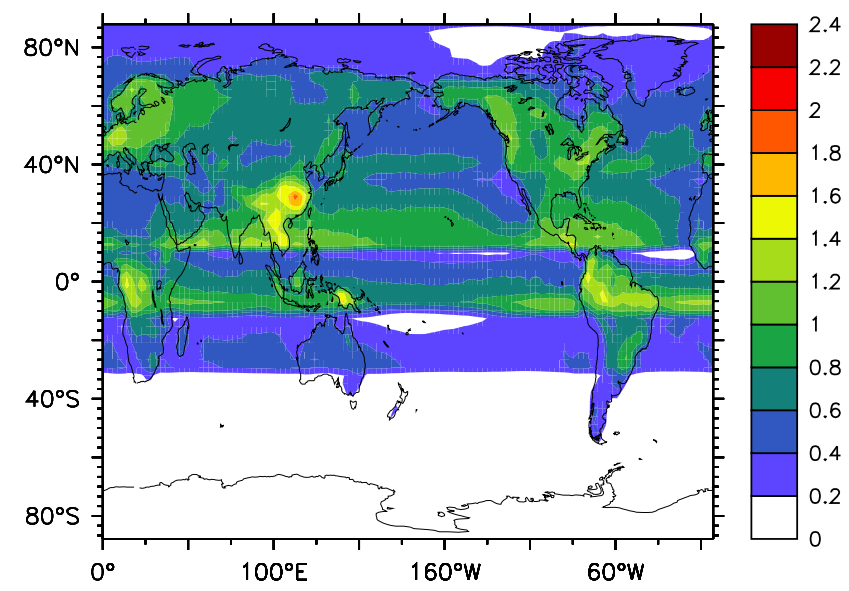

Fig. 17. Annual average (year 2000) of the $\mathrm{CH}_{3} \mathrm{Br}$ pseudo-emission flux $\left(10^{11}\right.$ molecules $\left./\left(\mathrm{m}^{2} \mathrm{~s}\right)\right)$ resulting from the tracer nudging in the lowest model layer.

denominates the bromine contained in all six previously investigated compounds and in the halons $\mathrm{CF}_{2} \mathrm{BrCl}$ and $\mathrm{CF}_{3} \mathrm{Br}$. "Reactive bromine" refers to bromine found in all gaseous compounds which are not organic bromine.

Table 7 lists the stratospheric and tropospheric globally integrated production in $\mathrm{kg}(\mathrm{Br}) / \mathrm{s}$ of $\mathrm{Br}$ radicals by photolysis of bromocarbons and reaction with $\mathrm{OH}$, respectively. As the reaction rate of bromoform with $\mathrm{OH}$ was not correct in the S-hal simulation, Table 7 also lists the corrected production of $\mathrm{Br}$ radicals from bromoform and the corrected total production. In the discussion below, always the corrected values are used. Figure 23 shows the vertical distribution of the total production of $\mathrm{Br}$ radicals. The bromocarbon production has also been corrected in this figure.

The degradation of bromocarbons is by far larger in the troposphere with a total production of $\mathrm{Br}$ radicals of $22.6 \mathrm{~kg}(\mathrm{Br}) / \mathrm{s}$. Reaction with $\mathrm{OH}$ amounts to $9.7 \mathrm{~kg}(\mathrm{Br}) / \mathrm{s}$, i.e. slightly more than $40 \%$ of the total amount. Conversely, this means that photolysis is the dominant source process accounting for approximately $60 \%$ of the bromine radical pro- duction from organic bromine. The stratospheric source is much smaller producing only $0.37 \mathrm{~kg}(\mathrm{Br}) / \mathrm{s}$ even though photolysis of $\mathrm{CH}_{3} \mathrm{Br}, \mathrm{CH}_{2} \mathrm{Br}_{2}$ and $\mathrm{CH}_{2} \mathrm{ClBr}$ is more efficient in the stratosphere than in the troposphere. In accordance with most stratospheric chemistry models (e.g. Steil et al., 1998; Teyssèdre et al., 2007), which usually take only methyl bromide into account, $\mathrm{CH}_{3} \mathrm{Br}$ is indeed the major source of reactive bromine in the upper stratosphere. Figure 23 shows that $\mathrm{CH}_{2} \mathrm{Br}_{2}$ is the $\mathrm{C}_{1}$-bromocarbon (except $\mathrm{CH}_{3} \mathrm{Br}$ ) contributing most to the reactive bromine production in the middle to upper stratosphere. Nevertheless, its contribution is more than one order of magnitude smaller than that of methyl bromide. More important is the photolysis of fluorinated halons. The brominated halons $\mathrm{CF}_{2} \mathrm{BrCl}$ and $\mathrm{CF}_{3} \mathrm{Br}$ were taken into account in our simulation and their photolysis yields about $14 \%$ of the overall stratospheric bromine production. Therefore the restriction of bromocarbon chemistry to methyl bromide (and additional fluorinated halons) in stratospheric models seems justified in view of our results for the upper stratosphere. For the lower stratosphere another bromocarbon gains importance: bromoform. It contributes approximately twice as much bromine radicals to the stratosphere as methyl bromide. As discussed in Sect. 3.1 even the corrected bromoform distribution tends to overestimate the amount of bromoform in the UTLS compared to the available measurements. From the profiles it can be roughly estimated that the bromoform content is overpredicted by a factor of 2 . Even if we take this factor into account, bromoform still provides the same amount of bromine radicals to the stratosphere as methyl bromide does. Thus, the contribution of bromoform to the reactive bromine content of the stratoshpere is not negligible. It rather contributes a subsantial amount of reactive bromine to the lower stratosphere. This result agrees very well with the findings of Dvortsov et al. (1999) and Nielsen and Douglas (2001) which both claim that bromoform contributes substantial amounts of $\mathrm{Br}_{\mathrm{y}}$ to the lower stratosphere. For this reason bromoform should not be neglected in stratospheric models for studies focussing on the UTLS. 

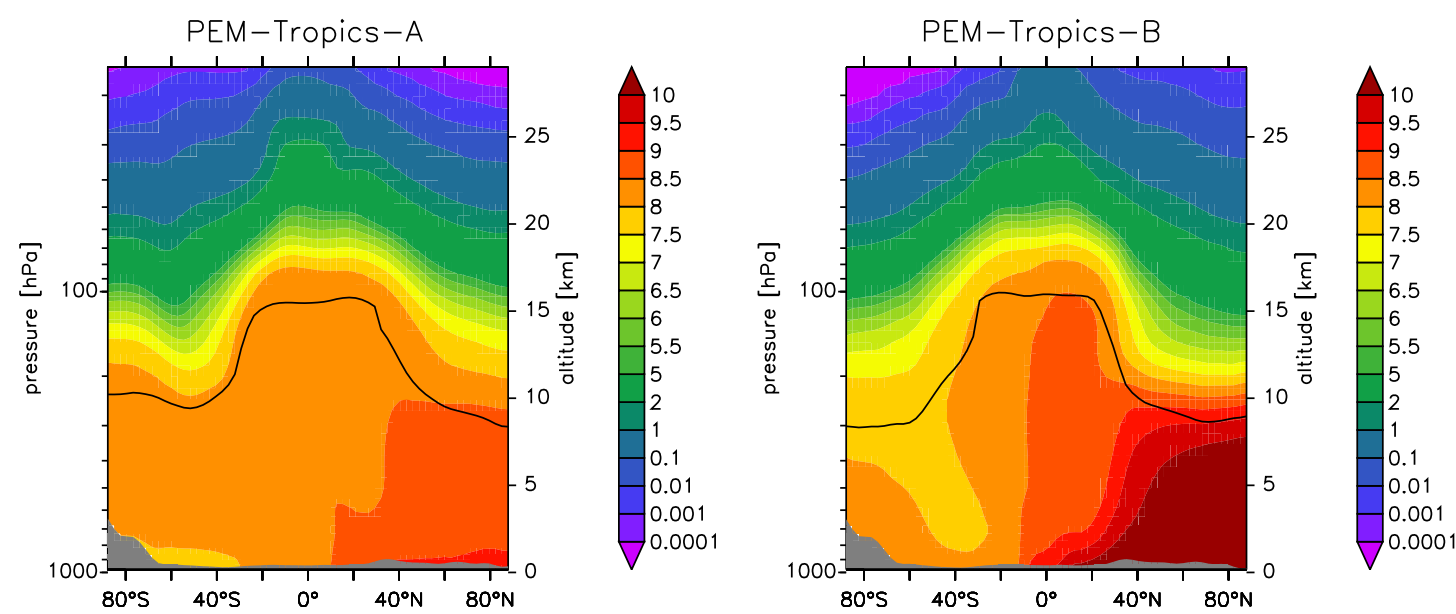

Fig. 18. Zonal averages of simulated $\mathrm{CH}_{3} \mathrm{Br}$ mixing ratios (pmol/mol). The periods coincide with the PEM-Tropics A (5 August-6 October) and PEM-Tropics B (6 March-16 April) campaigns, though for the year 2000.
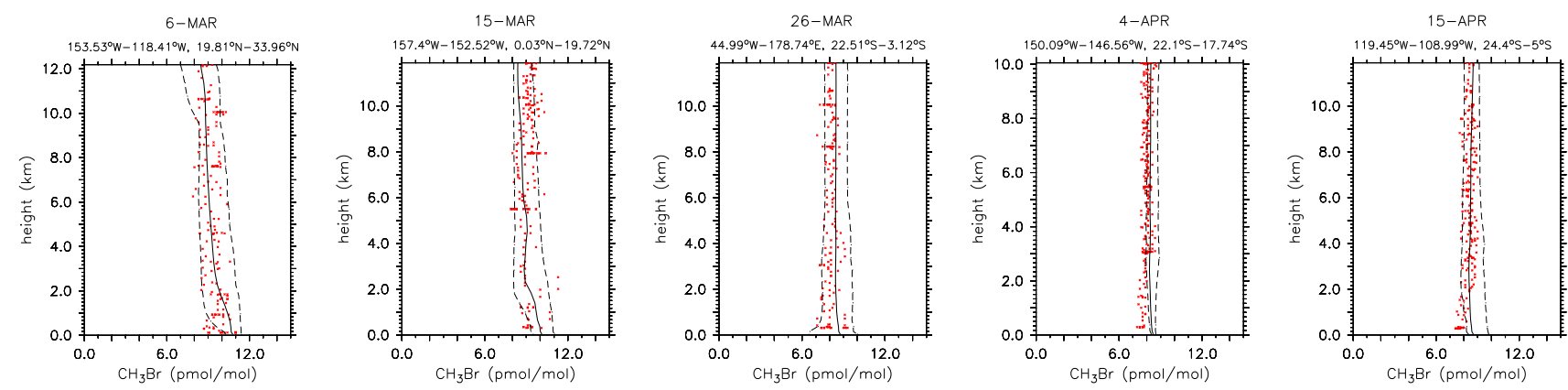

Fig. 19. $\mathrm{CH}_{3} \mathrm{Br}$ vertical profiles (pmol/mol) as measured during the PEM-Tropics B campaign (6 March-16 April, red dots). The black lines show the simulated vertical profiles averaged over the flight period and area. The dashed lines indicate the simulated minimum and maximum mixing ratios.

In summary, photolysis and reaction with $\mathrm{OH}$ are both important decomposition processes of bromocarbons in the troposphere although photolysis dominates. In the stratosphere the photolysis of halons contributes about $14 \%$ to the overall $\mathrm{Br}$ production. Bromoform degradation provides a substancial amount of reactive bromine to the lower stratosphere and thus should not be neglected in stratospheric simulations.

\section{Conclusions}

In this part of a series of articles, focussing on atmospheric bromine chemistry, we investigate the distribution of bromocarbons as simulated with the AC-GCM ECHAM5/MESSy. The applied emission fields follow the estimates of Warwick et al. (2006a), more specifically emission scenario 5 which gave the most reasonable results in their study. Depending on the bromocarbon species, the model tends to slightly underor overestimate the abundance. For bromoform the observed increase (PEM) from the free troposphere towards the surface is very well reproduced. The model predicts a slight increase towards higher altitudes while the observations indicate a decrease. The $\mathrm{CH}_{2} \mathrm{Br}_{2}$ mixing ratios are overestimated by the simulation for most PEM profiles. Nevertheless, the simulated profile shape, especially the observed increase in the mixing ratio towards the surface is reproduced by the simulation. Compared to the CARIBIC data the $\mathrm{CH}_{2} \mathrm{Br}_{2}$ mixing ratios tend to be overestimated in the UTLS.

The simulated $\mathrm{CH}_{2} \mathrm{ClBr}$ mixing ratios are generally too low compared to PEM and surface observations. On the other hand the simulated $\mathrm{CHClBr}_{2}$ mixing ratios are in agreement with the measurements (PEM+surface), while the simulated $\mathrm{CHCl}_{2} \mathrm{Br}$ mixing ratios are slightly underestimated compared to surface measurements and PEM-B data and partly overestimated for PEM-Tropics A.

Bromoform is too high in our simulation compared to the measurements which is due to an incorrect reaction rate for the reaction of $\mathrm{CHBr}_{3}$ with $\mathrm{OH}$. A sensitivity simulation 

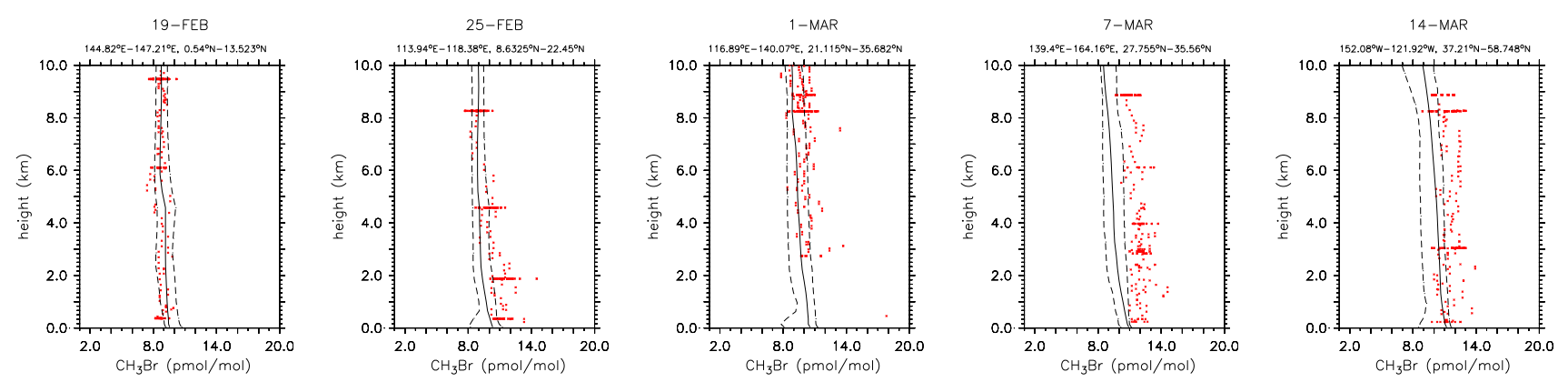

Fig. 20. As Fig. 4 for $\mathrm{CH}_{3} \mathrm{Br}$ but from PEM-West B (February-March 1994).
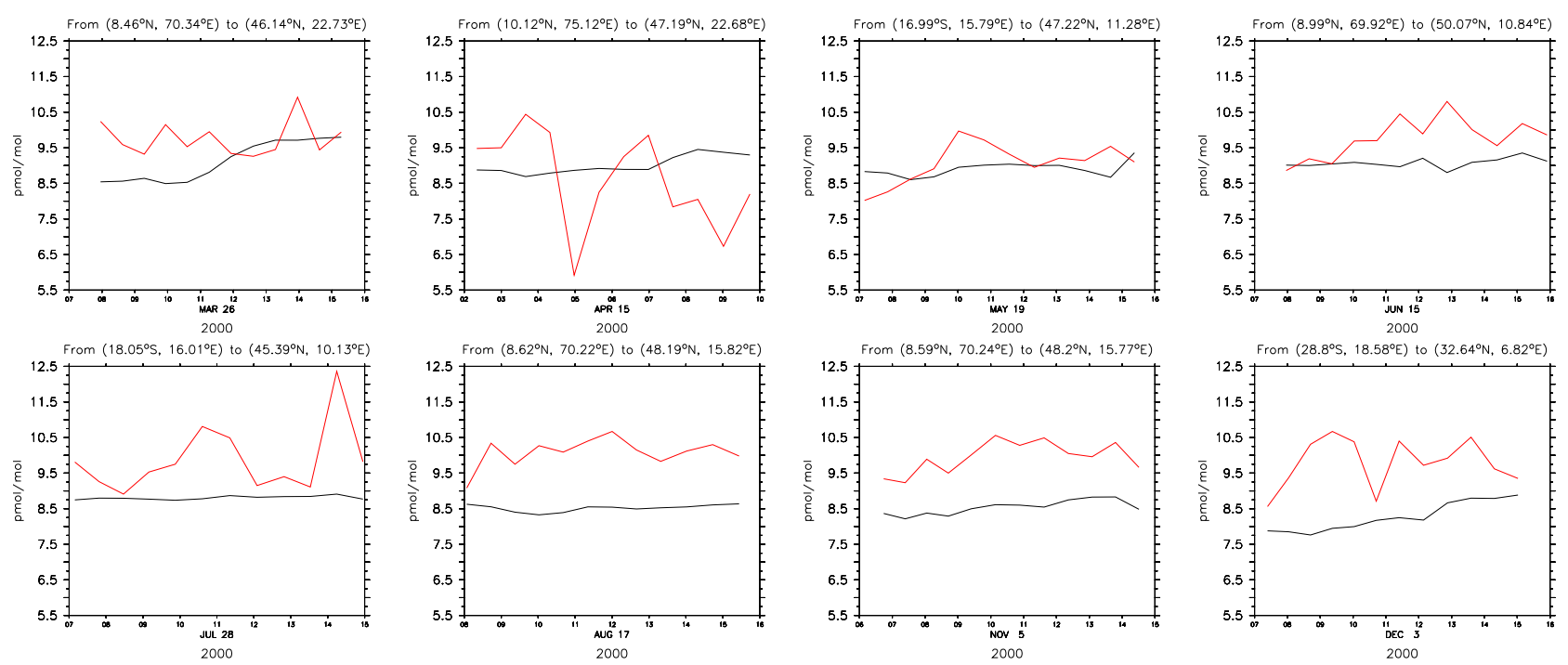

Fig. 21. Point to point comparison of $\mathrm{CH}_{3} \mathrm{Br}$ mixing ratios from CARIBIC aircraft data (red line) and model results (black) as a function of time of day from March-December 2000.

showed that bromoform profiles corrected for this rate agree well with the measurements in the free troposphere. The erroneous increase towards the UTLS is still apparent in the corrected profiles even though much smaller. We conclude that this increase is a consequence of an overestimated $\mathrm{CHBr}_{3}$ emission flux in the tropics. We applied the emission scenario proposed by Warwick et al. (2006b) with enhanced coastline emissions in the tropics. The emitted bromoform is efficiently transported upward by tropical deep convection yielding too much bromoform in the UTLS. In turn, this results in an overestimation of the Br-radical production in the lowermost stratosphere. Nevertheless, our simulation indicates that bromoform contributes substantial amounts of bromine to the lower stratosphere. This implies that stratospheric simulations should not neglect bromoform.

The simulated methyl bromide profiles match the observations very well in the tropics, whereas this agreement decreases somewhat towards the north. This is most likely caused by the simple assumptions about the surface mixing ratios of $\mathrm{CH}_{3} \mathrm{Br}$ used for the tracer nudging. The comparison with CARIBIC and GABRIEL data shows an underestimation for the same reason.

In summary, many bromocarbon mixing ratios are slightly overestimated by the model. However, as the measurements are mostly within the uncertainty of the simulation (and vice versa), we conclude that the agreement is relatively good while the shape of the vertical profiles and the total mixing ratios are realistically reproduced except the overestimations in the UTLS for $\mathrm{CHBr}_{3}$ and $\mathrm{CH}_{2} \mathrm{Br}_{2}$.

Based on the evaluated bromocarbon distributions the production processes of reactive bromine were investigated. Photolysis was found to be the dominant decomposition process in the stratosphere for all bromocarbons. In the troposphere reaction with $\mathrm{OH}$ is the dominant loss process for $\mathrm{CH}_{3} \mathrm{Br}, \mathrm{CH}_{2} \mathrm{Br}_{2}$ and $\mathrm{CH}_{2} \mathrm{ClBr}$, whereas photolysis is most important for $\mathrm{CHBr}_{3}, \mathrm{CHCl}_{2} \mathrm{Br}$ and $\mathrm{CHClBr}_{2}$. 

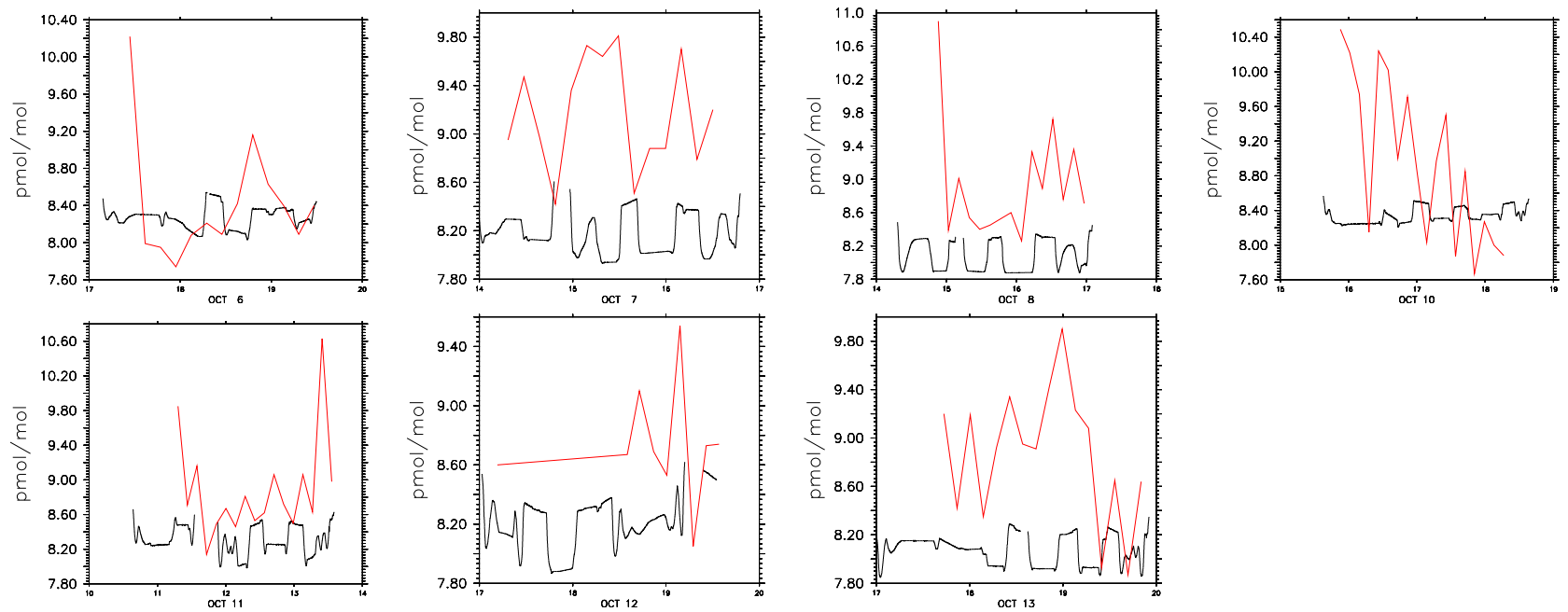

Fig. 22. Point to point comparison of $\mathrm{CH}_{3} \mathrm{Br}$ mixing ratios from GABRIEL aircraft data (red line) and model results (black) as a function of time of day in October 2000.
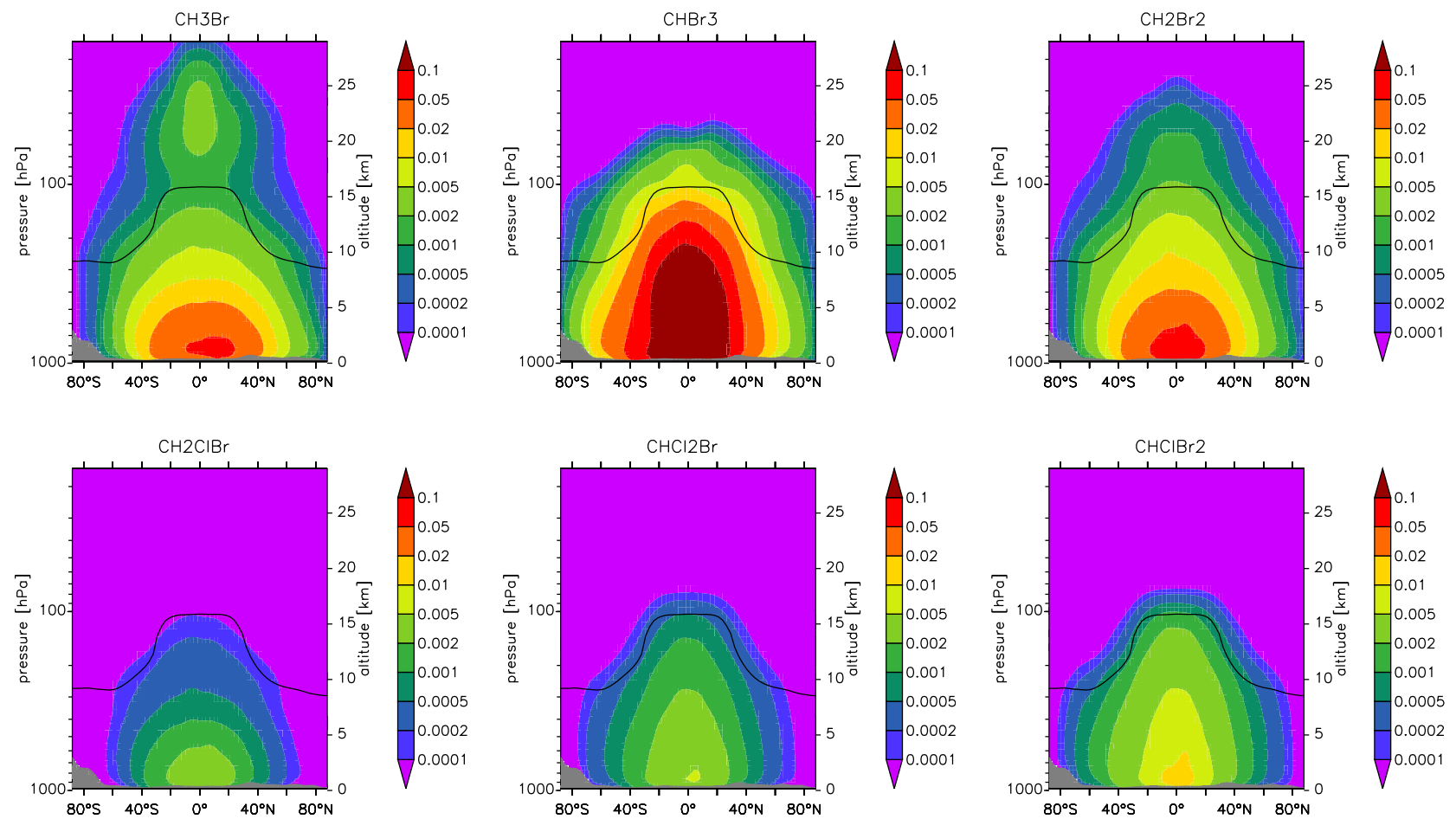

Fig. 23. Simulated production of Br radicals in $\mathrm{g}(\mathrm{Br}) / \mathrm{s}$ by bromocarbon photolysis and reaction with $\mathrm{OH}$. 
Table 7. Production of $\mathrm{Br}$ by photolysis $(h v)$ and reaction with $\mathrm{OH}$ in $\mathrm{kg} / \mathrm{s}$ in the stratosphere (strat) and troposphere (trop), respectively. The rates for the reactions of the halons have been calculated from the difference of the total $\mathrm{Br}$ production and the sum of the six bromocarbons. Furthermore, the values for bromoform and the total production corrected for the wrong reaction rate of bromoform with $\mathrm{OH}$ are displayed.

\begin{tabular}{lccrl}
\hline & \multicolumn{2}{c}{$h v$} & \multicolumn{2}{c}{$\mathrm{OH}$} \\
species & strat & trop & strat & trop \\
\hline $\mathrm{CH}_{3} \mathrm{Br}$ & 0.064 & 0.003 & 0.031 & 2.201 \\
$\mathrm{CHBr}_{3}$ & 0.211 & 15.804 & 0.003 & 0.713 \\
$\mathrm{CH}_{2} \mathrm{Br}_{2}$ & 0.022 & 0.006 & 0.043 & 2.588 \\
$\mathrm{CH}_{2} \mathrm{ClBr}$ & 0.002 & $<0.001$ & 0.003 & 0.123 \\
$\mathrm{CHCl}_{2} \mathrm{Br}$ & 0.003 & 0.124 & $<0.001$ & 0.102 \\
$\mathrm{CHClBr}_{2}$ & 0.007 & 0.332 & $<0.001$ & 0.183 \\
halons & 0.052 & 0.0 & 0.001 & 0.0 \\
total & 0.361 & 16.266 & 0.082 & 5.909 \\
\hline $\mathrm{CHBr}_{3}{ }^{\text {corr }}$ & 0.141 & 12.47 & 0.052 & 4.485 \\
total & 0.239 & 12.935 & 0.131 & 9.682 \\
\hline
\end{tabular}

This analysis focussed on the bromine source from bromocarbons. In Part 3 of this series we will investigate the importance of bromine release from sea salt aerosol and the resultant $\mathrm{Br}_{\mathrm{y}}$ distribution.

Acknowledgements. We thank all MESSy developers and users for their support. We are grateful for the use of the CARIBIC bromocarbon data measured by David Oram (University of East Anglia, Norwich, UK). We have used the Ferret program (http://www.ferret.noaa.gov) from NOAA's Pacific Marine Environmental Laboratory for creating the graphics in this paper. We acknowledge the effort of the three anonymeous referees whose comments were very helpful for improving the quality of this publication.

Edited by: M. Dameris

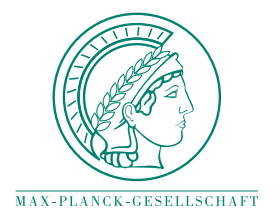

The publication of this article is financed by the Max Planck Society.

\section{References}

Andreae, M., Atlas, E., Harris, G., Helas, G., deKock, A., Koppmann, R., Maenhaut, W., Mano, S., Pollock, W., Rudolph, J., Scharffe, D., Schebeske, G., and Welling, M.: Methyl halide emissions from savanna fires in southern Africa, J. Geophys. Res., 101, 23 603-23 613, 1996.

Atlas, E., Schauffler, S. M., Merrill, J. T., Hahn, C. J., Ridley, B., Walega, J., Greenberg, J., Heidt, L., and Zimmerman, P.: Alkyl Nitrate and Selected Halocarbon Measurements at Mauna Loa Observatory, Hawaii, J. Geophys. Res., 97, 10 331-10348, 1992.

Blake, N., Blake, D., Chen, T., Collins, J., Sachse, G., Anderson, B., and Rowland, F.: Distribution and seasonality of selected hydrocarbons and halocarbons over the western Pacific basin during PEM-West A and PEM-West B, J. Geophys. Res., 102, 28315 28 331, 1997.

Blake, N., Blake, D., Simpson, I., Lopez, J., Johnston, N., Swanson, A., Katzenstein, A., Meinardi, S., Sive, B., Colman, J., Atlas, E., Flocke, F., Vay, S., Avery, M., and Rowland, F.: Largescale latitudinal and vertical distributions of NMHCs and selected halocarbons in the troposphere over the Pacific Ocean during the March-April 1999 Pacific Exploratory Mission (PEMTropics B), J. Geophys. Res., 106, 32 627-32 644, 2001.

Brenninkmeijer, C., Crutzen, P., Fischer, H., Gusten, H., Hans, W., Heinrich, G., Heintzenberg, J., Hermann, M., Immelmann, T., Kersting, D., Maiss, M., Nolle, M., Pitscheider, A., Pohlkamp, H., Scharffe, D., Specht, K., and Wiedensohler, A.: CARIBIC Civil aircraft for global measurement of trace gases and aerosols in the tropopause region, J. Atmos. Oc. Tech., 16, 1373-1383, 1999.

Buchholz, J.: Simulations of Physics and Chemistry of Polar Stratospheric Clouds with a General Circulation Model, Ph.D. thesis, Johannes Gutenberg-Universität, Fachbereich Physik, http://nbn-resolving.de/urn/resolver.pl?urn=urn:nbn:de: hebis:77-8187, 2005.

Carpenter, L. and Liss, P.: On temperate sources of bromoform and other reactive organic bromine gases, J. Geophys. Res., 105, 20 539-20 547, 2000.

Carpenter, L., Sturges, W., Penkett, S., Liss, P., Alicke, B., Hebestreit, K., and Platt, U.: Short-lived alkyl iodides and bromides at Mace Head, Ireland: Links to biogenic sources and halogen oxide production, J. Geophys. Res., 104, 1679-1689, 1999.

Carpenter, L. J., Wevill, D. J., O’Doherty, S., Spain, G., and Simmonds, P. G.: Atmospheric bromoform at Mace Head, Ireland: seasonality and evidence for a peatland source, Atmos. Chem. Phys., 5, 2927-2934, 2005,

http://www.atmos-chem-phys.net/5/2927/2005/.

Carpenter, L. J., Liss, P. S., and Penkett, S. A.: Marine organohalogens in the atmosphere over the Atlantic and Southern Oceans, J. Geophys. Res., 108, 4256, doi:10.1029/2002JD002769, 2003.

Class, T. and Ballschmiter, K.: Chemistry of Organic Traces in Air, J. Atmos. Chem., 6, 35-46, 1988.

Colman, J., Swanson, A., Meinardi, S., Sive, B., Blake, D., and Rowland, F.: Description of the analysis of a wide range of volatile organic compounds in whole air samples collected during PEM-Tropics A and B, Anal. Chem., 73, 3723-3731, 2001.

Dvortsov, V. L., Geller, M. A., Solomon, S., Schauffler, S. M., Atlas, E. L., and Blake, D. R.: Rethinking Reactive Halogen Budgets in the Midlatitude Lower Stratosphere, Geophys. Res. Lett., 26, 1699-1702, 1999. 
Emmons, L. K., Hauglustaine, D. A., Müller, J.-F., Carroll, M. A., Brasseur, G. P., Brunner, D., Staehelin, J., Thouret, V., and Marenco, A.: Data composites of airborne observation of tropospheric ozone and its precursor, J. Geophys. Res., 105, $20497-$ 20 538, 2000.

Gebhardt, S., Colomb, A., Hofmann, R., Williams, J., and Lelieveld, J.: Halogenated organic species over the tropical South American rainforest, Atmos. Chem. Phys., 8, 3185-3197, 2008, http://www.atmos-chem-phys.net/8/3185/2008/.

Giorgetta, M. A., Manzini, E., and Roeckner, E.: Forcing of the quasi-biennial oscillation from a broad spectrum of atmospheric waves, Geophys. Res. Lett., 29, 1245, doi:10.1029/2002GL014756, 2002.

Giorgetta, M. A., Manzini, E., Roeckner, E., Esch, M., and Bengtson, L.: Climatology and forcing of the quasi-biennial oscillation in the MAECHAM5 model, J. Climate, 19, 3882-3901, 2006.

Gros, V., Williams, J., van Aardenne, J. A., Salisbury, G., Hofmann, R., Lawrence, M. G., von Kuhlmann, R., Lelieveld, J., Krol, M., Berresheim, H., Lobert, J. M., and Atlas, E.: Origin of anthropogenic hydrocarbons and halocarbons measured in the summertime european outflow (on Crete in 2001), Atmos. Chem. Phys., 3, 1223-1235, 2003, http://www.atmos-chem-phys.net/3/1223/2003/.

Hoell, J. M., Davis, D. D., Liu, S. C., Newell, R. E., Akimoto, H., McNeal, R. J., and Bendura, R. J.: The Pacific Exploratory Mission-West Phase B: February-March 1994, J. Geophys. Res., 102, $28223-28239,1997$.

Hoell, J. M., Davis, D. D., Jacob, D. J., Rodgers, M. O., Newell, R. E., Fuelberg, H. E., McNeal, R. J., Raper, J. L., and Bendura, R. J.: Pacific Exploratory Mission in the tropical Pacific: PEM-Tropics A, August-September 1996, J. Geophys. Res., 104, 5567-5583, 1999.

Jöckel, P., Sander, R., Kerkweg, A., Tost, H., and Lelieveld, J.: Technical Note: The Modular Earth Submodel System (MESSy) - a new approach towards Earth System Modeling, Atmos. Chem. Phys., 5, 433-444, 2005,

http://www.atmos-chem-phys.net/5/433/2005/.

Jöckel, P., Tost, H., Pozzer, A., Brühl, C., Buchholz, J., Ganzeveld, L., Hoor, P., Kerkweg, A., Lawrence, M. G., Sander, R., Steil, B., Stiller, G., Tanarhte, M., Taraborrelli, D., van Aardenne, J., and Lelieveld, J.: The atmospheric chemistry general circulation model ECHAM5/MESSy1: consistent simulation of ozone from the surface to the mesosphere, Atmos. Chem. Phys., 6, 50675104, 2006, http://www.atmos-chem-phys.net/6/5067/2006/.

Kerkweg, A., Buchholz, J., Ganzeveld, L., Pozzer, A., Tost, H., and Jöckel, P.: Technical Note: An implementation of the dry removal processes DRY DEPosition and SEDImentation in the Modular Earth Submodel System (MESSy), Atmos. Chem. Phys., 6, 4617-4632, 2006a,

http://www.atmos-chem-phys.net/6/4617/2006/.

Kerkweg, A., Sander, R., Tost, H., and Jöckel, P.: Technical note: Implementation of prescribed (OFFLEM), calculated (ONLEM), and pseudo-emissions (TNUDGE) of chemical species in the Modular Earth Submodel System (MESSy), Atmos. Chem. Phys., 6, 3603-3609, 2006b,

http://www.atmos-chem-phys.net/6/3603/2006/.

Kerkweg, A., Sander, R., Tost, H., Jöckel, P., and Lelieveld, J.: Technical Note: Simulation of detailed aerosol chemistry on the global scale using MECCA-AERO, Atmos.
Chem. Phys., 7, 2973-2985, 2007, http://www.atmos-chemphys.net/7/2973/2007/.

Kerkweg, A., Jöckel, P., Pozzer, A., Tost, H., Sander, R., Schulz, M., Stier, P., Vignati, E., Wilson, J., and Lelieveld, J.: Consistent simulation of bromine chemistry from the marine boundary layer to the stratosphere, Part I: model description, sea salt aerosols and pH, Atmos. Chem. Phys., 8, 5899-5917, 2008,

http://www.atmos-chem-phys.net/8/5899/2008/.

Kourtidis, K., Borchers, R., and Fabian, P.: Dibromomethane $\left(\mathrm{CH}_{2} \mathrm{Br}_{2}\right)$ measurements at the upper troposphere and lower stratosphere, Geophys. Res. Lett., 23, 2581-2583, 1996.

Landgraf, J. and Crutzen, P.: An Efficient Method for Online Calculation of Photolysis and Heating Rates, J. Atmos. Sci., 55, 863878, 1998.

Lelieveld, J., Butler, T. M., Crowley, J. N., Dillon, T. J., Fischer, H., Ganzeveld, L., Harder, H., Lawrence, M. G., Martinez, M., Taraborrelli, D., and Williams, J.: Atmospheric oxidation capacity sustained by a forest, Nature, 452, 737-740, 2008.

Montzka, S., Butler, J., Hall, B., Mondeel, D., and Elkins, J.: A decline in tropospheric organic bromine, Geophys. Res. Lett., 30, 1826, doi:10.1029/2003GL017745, 2003.

Nielsen, J. E. and Douglas, A. R.: A simulation of bromoform's contribution to stratospheric bromine, J. Geophys. Res., 106, 8089-8100, 2001.

Penkett, S. A., Jones, B. M. R., Rycroft, M. J., and Simmons, D. A.: An interhemispheric comparison of the concentrations of bromine compounds in the atmosphere, Nature, 318, 550-553, doi:10.1038/318550a0, 1985.

Oram, D. E., Sturrock, G. A., Penkett, S. A., and Brenninkmeijer, C. A. M.: Distribution of halocarbons in the UTLS: overview of results from the CARIBIC experiment, 1997-2002, in preparation, 2008.

Pozzer, A., Jöckel, P., Sander, R., Williams, J., Ganzeveld, L., and Lelieveld, J.: Technical Note: The MESSy-submodel AIRSEA calculating the air-sea exchange of chemical species, Atmos. Chem. Phys., 6, 5435-5444, 2006, http://www.atmos-chem-phys.net/6/5435/2006/.

Prinn, R. G., Weiss, R. F., Fraser, P. J., Simmonds, P. G., Cunnold, D. M., Alyea, F. N., O’Doherty, S., Salameh, P., Miller, B. R., Huang, J., Wang, R. H. J., Hartley, D. E., Harth, C., Steele, L. P., Sturrock, G., Midgley, P. M., and McCulloch, A.: A history of chemically and radiatively important gases in air deduced from ALE/GAGE/AGAGE, J. Geophys. Res., 105, 17 751-17 792, 2000.

Ramacher, B., Rudolph, J., and Koppmann, R.: Hydrocarbon measurements during tropospheric ozone depletion events: Evidence for halogen atom chemistry, J. Geophys. Res., 104, 3633-3653, 1999.

Raper, J. L., Kleb, M. M., Jacob, D. J., Davis, D. D., Newell, R. E., Fuelberg, H. E., Bendura, R. J., Hoell, J. M., and McNeal, R. J.: Pacific Exploratory Mission in the Tropical Pacific: PEMTropics B, March-April 1999, J. Geophys. Res., 106, 32 40132 425, 2001.

Reeves, C.: Atmospheric budget implications of the temporal and spatial trends in methyl bromide concentration, J. Geophys. Res., 108, 4343, doi:10.1029/2002JD002943, 2003.

Roeckner, E., Bäuml, G., Bonaventura, L., Brokopf, R., Esch, M., Giorgetta, M., Hagemann, S., Kirchner, I., Kornblueh, L., Manzini, E., Rhodin, A., Schlese, U., Schulzweida, U., 
and Tompkins, A.: The atmospheric general circulation model ECHAM5, Tech. Rep. MPI-Report 349, Max Planck-Institute for Meteorology, Hamburg, http://www.mpimet.mpg.de/fileadmin/ publikationen/Reports/max_scirep_349.pdf , 2003.

Roeckner, E., Brokopf, R., Esch, M., Giorgetta, M., Hagemann, S., Kornblueh, L., Manzini, E., Schlese, U., and Schulzweida, U.: The atmospheric general circulation model ECHAM5. PART II: Sensitivity of Simulated Climate to Horizontal and Vertical Resolution, Tech. Rep. MPI-Report 354, Max PlanckInstitute for Meteorology, http://www.mpimet.mpg.de/fileadmin/ publikationen/Reports/max_scirep_354.pdf, 2004.

Roeckner, E., Brokopf, R., Esch, M., Giorgetta, M., Hagemann, S., Kornblueh, L., Manzini, E., Schlese, U., and Schulzweida, U.: Sensitivity of simulated climate to horizontal and vertical resolution in the ECHAM5 atmosphere model, J. Climate, 19, 3771-3791, 2006.

Sander, R., Kerkweg, A., Jöckel, P., and Lelieveld, J.: Technical note: The new comprehensive atmospheric chemistry module MECCA, Atmos. Chem. Phys., 5, 445-450, 2005,

http://www.atmos-chem-phys.net/5/445/2005/.

Sander, S. P., Finlayson-Pitts, B. J., Friedl, R. R., Golden, D. M., Huie, R. E., Kolb, C. E., Kurylo, M. J., Molina, M. J., Moortgat, G. K., Orkin, V. L., and Ravishankara, A. R.: Chemical Kinetics and Photochemical Data for Use in Atmospheric Studies, Evaluation Number 14, JPL Publication 02-25, Jet Propulsion Laboratory, Pasadena, CA, 2003.

Sander, S. P., Friedl, R. R., Golden, D. M., Kurylo, M. J., Moortgat, G. K., Keller-Rudek, H., Wine, P. H., Ravishankara, A. R., Kolb, C. E., Molina, M. J., Finlayson-Pitts, B. J., Huie, R. E., and Orkin, V. L.: Chemical Kinetics and Photochemical Data for Use in Atmospheric Studies, Evaluation Number 15, JPL Publication 06-2, Jet Propulsion Laboratory, Pasadena, CA, 2006.

Schall, C. and Heumann, K. G.: GC determination of volatile organoiodine and organobromine compounds in Arctic seawater and air samples, Fresen. J. Anal. Chem., 346, 717-722, 1993.

Schauffler, S., Heidt, L., Pollock, W. H., Gilpin, T., Vedder, J., solomon, S., Lueb, R., and Atlas, E.: Measurements of halogenated organic compounds near the tropical tropopause, Geophys. Res. Lett., 20, 2567-2570, 1993.

Schauffler, S., Atlas, E., Flocke, F., Lueb, R., Stroud, V., and Travnicek, W.: Measurements of bromine containing organic compounds at the tropical tropopause, Geophys. Res. Lett., 25, 317-320, 1998.

Simmonds, P., Derwent, R., Manning, A., Fraser, P., Krummel, P., O’Doherty, S., Prinn, R., Cunnold, D., Miller, B., Wang, H., Ryall, D., Porter, L., Weiss, R., and Salameh, P.: AGAGE observations of methyl bromide and methyl chloride at Mace Head, Ireland, and Cape Grim, Tasmania, 1998-2001, J. Atmos. Chem., 47, 243-269, 2004.

Simpson, W. R., von Glasow, R., Riedel, K., Anderson, P., Ariya, P., Bottenheim, J., Burrows, J., Carpenter, L. J., Frie, U., Goodsite, M. E., Heard, D., Hutterli, M., Jacobi, H.-W., Kaleschke, L., Neff, B., Plane, J., Platt, U., Richter, A., Roscoe, H., Sander, R., Shepson, P., Sodeau, J., Steffen, A., Wagner, T., and Wolff, E.: Halogens and their role in polar boundary-layer ozone depletion, Atmos. Chem. Phys., 7, 4375-4418, 2007, http://www.atmos-chem-phys.net/7/4375/2007/.

Steil, B., Dameris, M., Brühl, C., Crutzen, P., Grewe, V., Ponater, M., and Sausen, R.: Development of a chemistry module for
GCMs: first results of a multiannual integration, Ann. Geophys., 16, 205-228, 1998, http://www.ann-geophys.net/16/205/1998/.

Stevenson, D., Dentener, F., Schultz, M., Ellingsen, K., van Noije, T., Wild, O., Zeng, G., Amann, M., Atherton, C., Bell, N., Bergmann, D., Bey, I., Butler, T., Cofala, J., Collins, W., Derwent, R., Doherty, R., Drevet, J., Eskes, H., Fiore, A., Gauss, M., Hauglustaine, D., Horowitz, L., Isaksen, I., Krol, M., Lamarque, J., Lawrence, M., Montanaro, V., Muller, J., Pitari, G., Prather, M., Pyle, J., Rast, S., Rodriguez, J., Sanderson, M., Savage, N., Shindell, D., Strahan, S., Sudo, K., and Szopa, S.: Multimodel ensemble simulations of present-day and nearfuture tropospheric ozone, J. Geophys. Res., 111, D08301, doi:10.1029/2005JD006338, 2006.

Stickler, A., Fischer, H., Bozem, H., Gurk, C., Schiller, C., Martinez-Harder, M., Kubistin, D., Harder, H., Williams, J., Eerdekens, G., Yassaa, N., Ganzeveld, L., Sander, R., and Lelieveld, J.: Chemistry, transport and dry deposition of trace gases in the boundary layer over the tropical Atlantic Ocean and the Guyanas during the GABRIEL field campaign, Atmos. Chem. Phys., 7, 3933-3956, 2007,

http://www.atmos-chem-phys.net/7/3933/2007/.

Sturges, W., McIntyre, H., Penkett, S., Chappellaz, J., Barnola, J.M., Mulvaney, R., Atlas, E., and Stroud, V.: Methyl bromide, other brominated methanes, and methyl iodide in polar firn air, J. Geophys. Res., 106, 1595-1606, 2001.

Teyssèdre, H., Michou, M., Clark, H. L., Josse, B., Karcher, F., Olivié, D., Peuch, V.-H., Saint-Martin, D., Cariolle, D., Attié, J.-L., Nédélec, P., Ricaud, P., Thouret, V., van der A, R. J., VolzThomas, A., and Chéroux, F.: A new tropospheric and stratospheric Chemistry and Transport Model MOCAGE-Climat for multi-year studies: evaluation of the present-day climatology and sensitivity to surface processes, Atmos. Chem. Phys., 7, 58155860, 2007, http://www.atmos-chem-phys.net/7/5815/2007/.

Tost, H., Jöckel, P., Kerkweg, A., Sander, R., and Lelieveld, J.: Technical note: A new comprehensive SCAVenging submodel for global atmospheric chemistry modelling, Atmos. Chem. Phys., 6, 565-574, 2006a,

http://www.atmos-chem-phys.net/6/565/2006/.

Tost, H., Jöckel, P., and Lelieveld, J.: Influence of different convection parameterisations in a GCM, Atmos. Chem. Phys., 6, 54755493, 2006b, http://www.atmos-chem-phys.net/6/5475/2006/.

Tost, H., Jöckel, P., Kerkweg, A., Pozzer, A., Sander, R., and Lelieveld, J.: Global cloud and precipitation chemistry and wet deposition: tropospheric model simulations with ECHAM5/MESSy1, Atmos. Chem. Phys., 7, 2733-2757, 2007a, http://www.atmos-chem-phys.net/7/2733/2007/.

Tost, H., Jöckel, P., and Lelieveld, J.: Lightning and convection parameterisations - uncertainties in global modelling, Atmos. Chem. Phys., 7, 4553-4568, 2007b,

http://www.atmos-chem-phys.net/7/4553/2007/.

United Nations Environment Programme (UNEP): Fourteenth meeting of the parties to the Montreal Protocol on substances that deplete the ozone layer, Rep. U.N. Environ. Program. Ozone Secr. Pro. 14/3, 18 October 1998.

Vignati, E., Wilson, J., and Stier, P.: M7: An efficient size-resolved aerosol microphysics module for large-scale aerosol transport, J. Geophys. Res., 109, D22202, doi:10.1029/2003JD004486, 2004.

Warwick, N., Pyle, J., Carver, G., Yang, X., Savage, N., O'Connor, F., and Cox, R.: Global modeling of biogenic bromocarbons, 
J. Geophys. Res., 111, D24305, doi:10.1029/2006JD007264, 2006a.

Warwick, N., Pyle, J., and Shallcross, D.: Global modelling of the Atmospheric Methyl Bromide Budget, J. Atmos. Chem., 54, 133-159, doi:10.1007/s10874-006-9020-3, 2006b.

Wesely, M.: Parameterization of the surface resistances to gaseous dry depposition in regional-scale numerical models, Atmos. Environ., 23, 1293-1304, 1989.

WMO: Scientific Assessment of Ozone Depletion: 2006: Global ozone monitoring and research project, World Meteorological Organization, Geneva, Schwitzerland, Report No. 50, p. 572 ff., 2007.
Yang, X., Cox, R. A., Warwick, N. J., Pyle, J. A., Carver, G. D., O'Connor, F. M., and Savage, N. H.: Tropospheric bromine chemistry and its impacts on ozone: A model study, J. Geophys. Res., 110, D23311, doi:10.1029/2005JD006244, 2005.

Yokouchi, Y., Barrie, L. A., Toom, D., and Akimoto, H.: The seasonal variation of selected natural and anthropogenic halocarbons in the arctic troposphere, Atmos. Environ., 20, 1723-1727, 1996.

Yokouchi, Y., Mukai, H., Yamamoto, H., Otsuki, A., Saitoh, C., and Nojiri, Y.: Distribution of methyl iodide, ethyl iodide, bromoform, and dibromomethane over the ocean (east and southeast Asian seas and the western Pacific), J. Geophys. Res., 102, 88058807, 1997. 